\title{
IQ and Audit Quality: Do Smarter Auditors Deliver Better Audits?
}

\author{
Jenni Kallunki, University of Oulu, Finland \\ Juha-Pekka Kallunki, University of Oulu, Finland; Aalto University, Finland; Stockholm School \\ of Economics, Sweden \\ Lasse Niemi, Aalto University, Finland \\ Henrik Nilsson, Stockholm School of Economics, Sweden \\ Correspondence address: \\ Professor Lasse Niemi \\ Aalto University, School of Business, Department of Accounting \\ P.O. Box 21220, FIN-00076 AALTO, Finland \\ Lasse.Niemi@aalto.fi \\ Phone: +358403538058
}

Data availability: Data sources are described in the article. Data requests should be directed to the administrator of each database.

\section{Acknowledgements}

Accepted by Clive Lennox. An earlier version of this paper was presented at the 2017 Contemporary Accounting Research Conference, generously supported by the Chartered Professional Accountants of Canada. We are grateful to two anonymous reviewers, Clive Lennox (the Editor) and Michael Welker (the Editor-in-Chief) for insightful comments that have greatly improved this paper. We also thank Eli Amir, Daniel Aobdia (the discussant), Jere Francis, Mattias Hamberg, Kathleen Harris, Tomas Hjelström, Steven Kachelmeier, Patrick Kielty, S.M. Khalid Nainar, Per Olsson, Thomas Omer, Luke Phelps, Petri Sahlström, Hanna Setterberg, Heidi Vander Bauwhede, participants at the 2017 CAR Conference, the 2017 University of Florida International Conference on Assurance and Governance, the $6^{\text {th }}$ EIASM Workshop on Audit Quality, and seminar participants at Aalto University, University of Bristol, University of Exeter, WHU - Otto Beisheim School of Management, CPA Canada - Accounting and Governance Research Centre, University of Ottawa, and University of Maastricht for numerous comments and suggestions. We acknowledge Euroclear Sweden, Finansinspektionen, The Swedish Tax Authorities, and The Swedish Armed Forces for providing the requisite data, as well as Handelsbanken Research Foundation, The Swedish Research Council (VR), Finnish Savings Banks Group Research Foundation, Marcus Wallenberg Research Foundation, OP Group Research Foundation, Tauno Tönning Foundation, Suomen Arvopaperimarkkinoiden Edistämissäätiö, Finnish Cultural Foundation, and Academy of Finland (Project \#277055) for financial support. This study has been evaluated and approved by The Regional Ethical Review Board in Umeå, Sweden (DNR 08:074 Ö, DNR I3-0449/2009 and 2010-200-32 Ö). All remaining errors are our own. 


\title{
IQ and Audit Quality: Do Smarter Auditors Deliver Better Audits?
}

\begin{abstract}
This study examines the role of an individual auditor's cognitive ability in delivering highquality audits. Our results from analyzing archival data from Sweden show that audit partners' IQ scores obtained from psychological tests are positively associated with going-concern audit reporting accuracy and audit fee premiums. We also find some, albeit weak, evidence that audit partners' IQ scores are negatively associated with the income-increasing abnormal accruals of the client. These results suggest that although audit services are standardized through various control mechanisms and audits are conducted by teams rather than by individual auditors, the cognitive ability of audit partners responsible for an audit remains important in delivering high-quality audit services.
\end{abstract}

JEL Classification: M41, M42

Keywords: Audit quality, Audit partners, Cognitive ability, IQ 


\section{Introduction}

Recently, much archival research has been devoted to individual auditors because of limitations with using the audit firm as the unit of analysis (Lennox and Wu 2018). This research shows that audit quality varies within an audit firm, and that much of this variation is attributable to the characteristics of the individual auditors in charge of audit engagements (Amir et al. 2014; Cameran et al. 2017; Carey and Simnett 2006; Chen et al. 2010; Chi and Chin 2011; Gul et al. 2013; and Knechel et al. 2015). However, it is not fully understood why audit quality varies between individual auditors. ${ }^{1}$ Due to the lack of person-level data on auditors, there is no archival evidence on the role of personal capabilities in the delivery of high-quality audits. Moreover, in many countries the identities of the audit partners in charge of an audit engagement are unknown, because audit reports are signed by audit firms rather than the individual auditors in charge of the audit engagements.

Experimental studies suggest that cognitive ability plays an important role in judgment and decision making during the audit process (Bonner and Lewis 1990; Gibbins 1984; Nelson and Tan 2005; and Libby and Luft 1993), but it remains unclear whether audit quality varies with auditors' IQ in practice. This is because audit firms mitigate the risk of individual auditors delivering low-quality audits by establishing various control mechanisms (Bedard et al. 2008), by promoting in-house knowledge sharing (Dowling 2009), and by organizing audit work as a joint effort by the audit team comprising several individual auditors (Rich et al. 1997). Thus, an important, yet largely unsolved question is whether an auditor's cognitive ability is associated with audit quality. Our study contributes to the literature by providing empirical evidence on the association between an audit partner's cognitive ability (IQ) and audit quality

1 An auditor's industry expertise and demographic factors such as gender or age have been linked to audit quality (Chin and Chi 2009; Chi and Chin 2011; Gul et al. 2013; Hardies et al. 2016; Ittonen et al. 2015; and Zerni 2012). However, these studies do not address the role of an auditor's cognitive ability in delivering high quality audits. 
as measured by going-concern audit reporting accuracy, audit fees, and abnormal accruals of the client. ${ }^{2}$

We conduct our study using data from Sweden for two reasons. First, the scores from an IQ test similar to the Armed Forces Qualifications Test (AFQT) used in the US are available for virtually all Swedish male citizens because military service was compulsory for all males in Sweden until 2010. ${ }^{3}$ Swedish male citizens were obliged by law to attend the enlistment test, including comprehensive psychological tests, to assess their cognitive ability. There is much research evidence that validates IQ as a measure of cognitive ability. Specifically, many studies show that an individual's IQ is a powerful predictor of her success in terms of salary and other income or job complexity (Beauchamp et al. 2017; Borghans et al. 2008; Hunter and Hunter 1984; Hülsheger et al. 2007; Lo 2017; Murray 1998; and Salgado et al. 2003). IQ has also been reported to be correlated with better performance in various decision-making situations and with the probability of having a top position in the corporate world (Adams et al. 2015; Grinblatt et al. 2011, 2012, 2015; and Keloharju et al. 2016).

The IQ test results from the Swedish military service are extremely reliable due to lack of incentives to avoid military service by 'flunking' the test: virtually all males with sufficient physical and psychological conditions were enlisted (Lindqvist and Westman 2011). In addition, the professional psychologists conducting the IQ test also double-checked each individual's background information, including his school grades, to ensure that the test result was plausible. If the test result seemed abnormally low, the individual had to retake the test.

2 The American Psychological Association defines cognitive ability (IQ) as "the ability to understand complex ideas, to adapt effectively to the environment, to learn from experience, to engage in various forms of reasoning, to overcome obstacles by taking thought" (Neisser et al. 1996, 77).

3 These tests are based on the methodologies developed in the psychological literature and are conducted by professional psychologists. 
Second, during our data period from 2000 - 2009, all public and private Swedish companies regardless of their size were required to file audited financial statements and the audit partner responsible for the audit engagement was required to sign the audit opinion. Combined, these characteristics of the Swedish setting allow us to trace the IQ score for 407 individual male audit partners and their 31,969 private and 277 public clients during our data period. The average audit partner in our sample has, on a scale from one to nine, an IQ score of 6.82, which is higher than the average IQ of the rest of the population, which is 5.0. There is also substantial variation in IQ among the audit partners, suggesting that an audit partner's IQ could indeed play a role in the quality of their audits.

Our empirical results show that audit quality increases with an audit partner's IQ score. Specifically, we find that the likelihood of issuing an incorrect going-concern audit report significantly decreases as the audit partner's IQ increases. This result holds for Total reporting error (the sum of Type 1 and Type 2 reporting errors) and for Type 1 and Type 2 reporting errors separately. We also find a significant increase in audit fees in accordance with an audit partner's IQ, suggesting that clients are willing to pay a fee premium for the services of more capable audit partners. Finally, we find some, albeit weak, evidence that the client's incomeincreasing earnings management decreases as the audit partner's IQ increases. We measure earnings management by abnormal accruals estimated using the modified Jones (1991) model (Caramanis and Lennox 2008). Overall, our results suggest that although an audit is a product of the joint effort of the whole audit team and is standardized and monitored by various mechanisms of the audit firm and the audit profession, the judgments and decisions made by the individual auditor in charge of the audit still play an important role in determining audit quality.

This study is subject to several limitations. Audit quality is a complex concept involving many dimensions which are not directly observable for outsiders. Audit quality must therefore 
be measured using proxies that contain measurement error. In an attempt to mitigate such errors, we use several audit quality proxies frequently used in previous studies, i.e. goingconcern reporting accuracy, audit fees, and abnormal accruals of the client (Defond and Zhang 2014; Simnett et al. 2016). Each of these proxies has unique strengths and weaknesses that are discussed in more detail in section $3 .^{4}$

Endogeneity is always a concern in archival studies like this one. In particular, an audit partner's IQ could be a proxy for omitted variables correlated with both auditor ability and audit quality, or the direction of causation could run from clients with higher audit quality to the use of more capable auditors. For example, clients with high quality financial reporting, a more complex business model, or that are greater in size may choose smarter auditors. In addition, data availability imposes some limitations on the analyses. In particular, because audit fees are not readily available for privately held companies in Sweden, the audit fee analyses in this paper are based on publicly listed companies only.

We believe that our results will be of interest to audit firms that select and promote their auditors. We also believe that the regulatory bodies that supervise the audit profession will be interested in our results. For instance, the Public Company Accounting Oversight Board (PCAOB) recently mandated the disclosure of the engagement partner's name for audits of US listed companies beginning in 2017.

The rest of the paper is organized as follows. In section 2, we discuss whether individual auditor cognitive ability may matter in audit quality. In section 3, we describe the institutional setting and research methodology. Empirical results are provided in section 4, and concluding remarks are provided in section 5 .

${ }^{4}$ A review article by Defond and Zhang (2014) provides an insightful discussion on the pros and cons of the various proxies for audit quality. 


\section{Relevant Literature}

\section{Why an auditor's cognitive ability may matter for audit quality}

An auditor's cognitive ability may matter for audit quality, because auditing is a complex process that requires many subjective judgments and decisions on the part of the auditor at all stages of the audit engagement, from the planning of the audit to the formation of the audit opinion (Hogarth 1991; Knechel 2000). Smart auditors also have incentives to exercise their cognitive skills to deliver high quality audits because they are rewarded for high quality audits and penalized for audit failures (Knechel et al. 2013).

\section{Subjective judgments and decision making in auditing}

Auditing is a complex process that requires subjective judgments and decisions at all stages of the audit engagement, including the planning of the audit, the collection and evaluation of audit evidence, and, finally, the formation of the audit opinion after the audit has been completed (Gibbins 1984; Hogarth 1991; and Knechel 2000). Subjective judgments and decisions regarding the nature, extent, and timing of the audit procedures are many, and they determine the success of the audit work. For instance, auditors assess whether complex accounting transactions are in accordance with GAAP. They also assess the economic estimates provided by the client for measuring asset and liability values. These estimates likely involve a great deal of discretion arising from the uncertainty of the outcome of future events or from using data that cannot be accumulated on a timely, cost-effective basis (Griffith et al. 2013).

Despite the difficulties in conducting well-controlled experiments in intelligence research (Lo 2017), there are experimental studies that link an auditor's cognitive ability to audit outcomes (Abdolmohammadi and Shanteau 1992; Bonner and Lewis 1990; Libby and Tan 1994; and McKnight and Wright 2011). Bonner and Lewis (1990) model auditor expertise as 
a function of knowledge and ability in various auditing tasks. They argue that auditors possess both knowledge and a general problem-solving ability, which includes the ability to recognize relationships, interpret data, and reason analytically. They find that, although more experienced auditors outperform less experienced auditors on average, knowledge and innate ability provide a better explanation of variation in auditor performance.

Libby and Tan (1994) also report that problem-solving ability affects an auditor's decision performance in unstructured tasks and that knowledge is related to ability through learning. Tan and Libby (1997) show that staff and senior auditors with superior performance evaluations have higher cognitive ability. They also find that ability does not matter for staff performance evaluations, if these evaluations mostly reflect work on simple tasks. Abdolmohammadi and Shanteau (1992) report that intelligence is among the most important attributes of an audit partner, thereby highlighting the importance of auditors' cognitive skills. Finally, McKnight and Wright (2011) report that both technical knowledge and ability are higher among high-performing auditors than among low-performing auditors.

\section{Incentives to deliver high quality audits}

Audit quality is a continuous construct in both theory and practice, ranging from very low to very high audit quality (Defond and Zhang 2014; Francis 2004). Audit failures such as audit reporting errors obviously occur on the lower end of the quality continuum. Auditors have incentives to avoid audit failures that expose them and their audit firms to litigation, reputation, and regulation risks (Defond and Zhang 2014). Litigation risk exposes auditors to financial penalties, whereas reputation risk impairs the ability to attract and retain clients. Regulation risk arises from the threat of regulatory intervention, which subjects auditors to sanctions that include fines, loss of licensure, and criminal penalties. These risks are not independent as litigation and regulatory sanctions are likely to damage the auditor's reputation as well. 
Auditors also have incentives to supply high audit quality because greater auditor competency in delivering high quality audits is likely to increase the auditor's reputation capital (Defond and Zhang 2014). Archival studies show that audit quality varies across individual audit partners and that both audit clients and audit firms reward their auditors for high quality audits (Amir et al. 2014; Aobdia et al. 2015; Cameran et al. 2017; Carey and Simnett 2006; Chen et al. 2010; Chi and Chin 2011; Gul et al. 2013; and Knechel et al. 2015). Archival studies also report that some of the auditor-level variation in audit quality is attributable to audit partners' personal characteristics (Chu et al. 2017; Gul et al. 2017; Hardies et al. 2016; Li et al. 2017; and Sundgren and Svanström 2014), and that audit fees vary across audit partners (Taylor 2011).

Taylor (2011) finds that there are "premium" partners who have fewer clients and shorter tenure than "discount" partners within the same audit firm. These "premium" partners can establish their reputation and move to more prestigious clients while the "discount" partners cannot establish such a reputation and serve only less prestigious clients. Zerni (2012) finds that the auditor-specific premium is associated with their industry specialization. Goodwin and $\mathrm{Wu}$ (2014) find that the audit fee premium related to an auditor's industry expertise is mainly a partner-level phenomenon. Finally, audit firms seem to reward their partners differently as there is significant variation in partner remuneration even within the same audit firm (Burrows and Black 1998; Knechel et al. 2013).

\section{Why an auditor's cognitive ability may not matter for audit quality}

There are also arguments for why an auditor's cognitive ability may not matter for audit quality. First, audit firms reduce the potential litigation and reputational losses from lowquality audits by controlling the behavior and decision-making of individual auditors and by enhancing the skills and adoption of best practices among auditors (Bedard et al. 2008; 
Dowling 2009). Second, audits are conducted by teams comprising several individuals, which is likely to reduce the role of an individual auditor in the production of audits (Rich et al. 1997). Finally, the professional qualifications of becoming a certified auditor (CPA) serve as entry requirements into the audit profession, which could prevent individuals with a low IQ from entering the profession.

Risk management, control mechanisms and knowledge sharing in audit firms

Audit firms are typically organized in the form of a partnership in which each audit partner is at the same time both an agent and a principal, sharing the risks (Huddart and Liang 2003). To protect the partnership against excessive risk-taking, audit firms create various monitoring mechanisms to control the behavior and decision-making of individual audit partners. These controls relate to all phases of audit engagement from client acceptance to audit procedures, and to quality control reviews of the completed work (Bedard et al. 2008).

Audit firms, moreover, develop their own unique audit approaches and styles to standardize their audits (Francis et al. 2014; Lemon et al. 2000). Audit approaches and styles are further reinforced by in-house knowledge-sharing systems, which make the research, experiences, processes, and working papers of audit teams available for everyone in the audit firm (Chow et al. 2008; Murthy and Kerr 2004; and Vera-Munõz et al. 2006). These systems enhance the skills of the members of audit teams and the adoption of best practices (Dowling 2009). Knowledge-sharing systems also restrict the audit partners' discretion in their judgment and decision making as each audit firm has its own in-house rules for how to interpret auditing and financial reporting standards. Finally, standard-setters, such as the International Auditing and Assurance Standards Board (IAASB), also require audit firms to establish procedures for systematic reviews to control the quality of their audit work. 
An audit is a joint-effort by an audit team

Since audits are conducted by teams, not individuals, the outcome of an audit depends on the work of the audit team. Although audit partners are involved in all important audit decisions and their views affect the judgments of the rest of the audit team (Peytcheva and Gillett 2011; Wilks 2002), the work of others still affects the decisions made by audit partners. Specifically, junior members of an audit team conduct most of the detailed audit fieldwork and senior members are responsible for coordinating this work and for reviewing the notes prepared by the juniors. Audit engagement partners plan and manage the audit engagement, review senior members' work, and are responsible for audit quality and the client relationship. Finally, audit review partners review the overall audit work and assess the audit engagement risks. Their views are likely to affect engagement partners' decisions.

Organizing audit work through teams, where individuals at different hierarchical levels of audit firms review the work of their subordinates, is an important quality control mechanism (Nelson and Tan 2005; Ramsay 1994). From the risk management point of view, engagement quality review partners are a critical organizational layer in audit firms because their primary objective is to evaluate the overall quality of the audit engagement and the performance of the engagement partners and their team (Epps and Messier 2007). To maintain their independence from those who conduct the audit, engagement quality reviewers are not allowed to belong to the audit team. The interaction between the engagement quality reviewers and the engagement partner is often centered on resolving difficult and complex accounting issues for the client (Emby and Favere-Marchesi 2010).

\section{Professional and personal qualifications for becoming an audit partner}

There are specific entry requirements for the audit profession that could prevent low-IQ individuals from entering this profession. In particular, an academic degree and passing a 
demanding exam are required to become a CPA. Current partners in an audit firm are most likely to invite only the most promising CPAs to join the partnership. Thus, audit partners pass several screenings during their career, and only the most capable auditors are likely to pass these screenings. Consequently, most audit partners are likely to have a high IQ and, therefore, provide high audit quality.

\section{Institutional setting and research methodology}

Institutional setting in Sweden

Audit regulation

As a member of the European Union (EU), Sweden follows the EU Directives and the ISA Standards on auditing. The EU regulation on auditing is implemented through the Accounting Act, the Auditing Act, and the Company Act, supplemented by the auditing standards of the Professional Institute for Certified Auditors and other Accounting Professionals (FAR). FAR is a member of the International Federation of Accountants (IFAC) and has adopted the ISA Standards and the IFAC's Code of Ethics.

In Sweden, both audit firms and their partners in charge of the audits of listed firms are subject to quality control inspections every three years. If their clientele comprises only private firms, this quality control is conducted every six years. There was no mandatory audit partner or firm rotation in Sweden during the sample period. Sweden has a two-tier system of auditor qualifications: approved and authorized auditors. The requirements to become an authorized auditor are more demanding. To become an authorized auditor, one must have a master's degree in accounting, practice of at least five years, and must pass a demanding professional competence examination. To become an approved auditor, one must have a bachelor's degree and practice for at least three years. Approved auditors who have passed a professional competence examination that is less demanding than that of authorized auditors are also 
allowed to audit all companies irrespective of their size. The audit certification is valid for five years, and the auditor must reapply to the supervisory board for a license renewal.

\section{Disclosures on audits}

Swedish legislation requires the auditor-in-charge to sign the audit report, and, if the report is signed by more than one auditor, the auditor-in-charge must be specified. The audit partnerin-charge of the audit engagement is legally responsible for the audit quality. Marketing of individual auditors plays an important role for success in the auditing procurement process (Zerni 2012). For instance, competitive bids disclosed to potential clients typically contain detailed descriptions of each audit team member and their planned tasks. Competitive bids also often include the curriculum vitae of the engagement partner and other key members of the audit team, suggesting that audits are not perceived as uniform among audit partners within audit firms (Fiolleau et al. 2010). Potential clients often request this information, indicating that providing an auditor's detailed curriculum vitae is an important signal that the engagement team has the relevant competence to carry out the audit work.

\section{Data sources and sample construction}

We use multiple sources to construct the data set for our empirical analyses. We begin by obtaining the information on the identity of individual audit partners from Finansinspektionen (the Swedish Financial Supervisory Authority). The data include all audit partners who have acted as a lead or deputy auditor for at least one listed Swedish company during the sample period from 2000 to 2009 . We obtain the IQ scores for these audit partners from the cognitive ability test data maintained by the Swedish Armed Forces. ${ }^{5}$ The resulting sample contains the

${ }^{5}$ IQ scores are not available for women and non-Swedes because they are not obligated to serve in the Swedish Armed Forces. 
IQ scores for 407 male auditors, for whom we then retrieved financial statement data for their listed clients from Compustat Global Vantage, and for their privately held clients from the database provided by Sweden's leading business and credit agency UC AB. ${ }^{6}$ The data include financial statements, audit reports, and information on bankruptcies. We exclude finance and insurance industries due to their unique financial reports and regulations.

We conduct three sets of empirical analyses to explore the association between auditors' IQ and audit quality. The number of observations varies across these three analyses because of the limitations arising from the calculations of different audit quality proxies. The goingconcern reporting accuracy analyses are based on a sample of 31,969 privately held clients (120,942 client-year observations) and 257 publicly listed clients (1,070 client-year observations) audited by 407 unique audit partners in 54 unique audit firms (five Big $\mathrm{N}$ firms and 49 non-Big $\mathrm{N}$ firms). ${ }^{7}$ There are 823 going-concern reports issued by 243 unique audit partners, 665 Type 1 reporting errors made by 222 unique audit partners, and 581 Type 2 reporting errors made by 213 unique audit partners. More details are given in Table 3.

The audit fee analyses are based on a sample of 277 publicly listed clients $(1,197$ clientyear observations) audited by 286 unique audit partners in 30 unique audit firms (five Big $\mathrm{N}$ firms and 25 non-Big $\mathrm{N}$ firms). We include only publicly listed companies in the audit fee analyses because the data on audit fees are not readily available in any database for Swedish privately held companies. Finally, the abnormal accruals analyses are based on a sample of 26,673 privately held clients (104,243 client-year observations) and 226 publicly listed clients

\footnotetext{
${ }^{6}$ Our sample selection criteria work against finding a relation between auditors' IQ and audit quality because all the auditors in our sample are authorized auditors who have experience of auditing listed companies, and the majority of them work for Big N audit firms.

${ }^{7}$ In untabulated analyses, we have restricted the sample to include only financially distressed clients. Financial distress is defined as having above median value of the variable $P R O B Z_{j t}$, or alternatively, having a negative net income (the dummy variable $L O S S_{j t}$ equals one). These results are essentially similar to those reported in the paper and are available from the authors upon request.
} 
(926 client-year observations) audited by 406 unique audit partners in 53 unique audit firms (four Big $\mathrm{N}$ firms and 49 non-Big $\mathrm{N}$ firms).

\section{Measurement of variables}

Audit quality proxies

Going-concern reporting error. We use going-concern reporting errors as an inverse measure of audit quality because issuing an incorrect going-concern audit report (issuing a going-concern audit report to a client that does not subsequently go bankrupt, or alternatively, not issuing a going-concern audit report to a client that subsequently goes bankrupt) can be regarded as an indication of low audit quality (DeFond and Zhang 2014; Lennox 1999; Knechel and Vanstraelen 2007; and Knechel et al. 2015). ${ }^{8}$ The advantage of using goingconcern audit reports in measuring audit quality is that they are a very direct measure of audit quality because the audit report is the auditor's responsibility and directly under her influence and control (Defond and Zhang 2014). They, moreover, involve relatively low measurement error. The disadvantage is that the egregious nature of going-concern audit reports means that they do not capture more subtle compromises in audit quality and are relatively rare events (Defond and Zhang 2014).

We construct the following three dummy variables to measure going-concern audit reporting errors. The dummy variable for Type 1 reporting error, TYPE_1_ERROR $E_{j t}$, equals one if an audit partner issues a going-concern audit report to a client that subsequently does not file for bankruptcy within 12 months of the audit partner's report, and zero otherwise. The dummy variable for Type 2 reporting error, TYPE_2_ERROR $R_{j}$, equals one if an audit partner

\footnotetext{
8 The term correct/incorrect audit going-concern report is a simplification as an auditor's task is to assess future financial distress or bankruptcy using present - not future information. Thus, clean/goingconcern audit reports might be correct in the light of present information even though they turn out to be erroneous when it comes to predicting bankruptcy. We thank a reviewer for pointing this out.
} 
does not issue a going-concern audit report to a client that subsequently files for bankruptcy within 12 months of the audit partner's report, and zero otherwise. The dummy variable for Total reporting error (the sum of Type 1 and Type 2 errors), TOTAL_ERROR $R_{j t}$, equals one if either of the dummy variables $T Y P E_{-}{ }_{1} \_E R R O R_{j t}$ or $T Y P E_{-} 2_{-} E R R O R_{j t}$ equals one, and zero otherwise. In cases with successive going-concern reports, we also include the subsequent going-concern report(s) to allow for learning effects. Specifically, if the first-time goingconcern report turned out to be erroneous, an auditor may be more accurate the next year. In untabulated analyses, we have replicated both the univariate and multivariate analyses reported in Tables 3 and 4 by using only first-time going-concern reports, and obtain essentially similar results.

Audit fees. We use audit fees to proxy for audit quality because they are expected to measure the auditor's effort level, which is an input to the audit process that is intuitively related to audit quality (Defond and Zhang 2014). The advantage of using audit fees as a measure of audit quality is that they are continuous and, thus, able to capture more subtle variations in audit quality. One limitation is that, in addition to capturing audit effort, audit fees also capture risk premium and improved audit efficiency, meaning that an increase in fees cannot unambiguously be interpreted as an increase in audit quality. Another limitation is that audit fees capture the joint outcome of both supply and demand factors (Defond and Zhang 2014). To measure audit fees, we construct a variable $\ln \left(A U D I T F E E S_{j t}\right)$, which is the natural logarithm of the audit fees paid by a client.

Abnormal accruals. Our third proxy for audit quality is the client's financial reporting quality as measured by abnormal accruals (Caramanis and Lennox 2008; Dechow et al. 2010; DeFond and Zhang 2014; and Francis et al. 2014). Financial reporting quality is an intuitively appealing proxy for audit quality because financial statements are a joint product of both the client and the auditor (DeFond and Zhang 2014). While abnormal accruals do not directly 
identify GAAP violations, they are expected to detect within GAAP earnings management, which likely impairs financial reporting quality by misleading investors. However, abnormal accruals are a less direct proxy for audit quality than, for example, going-concern audit reports because the auditor's influence on the client's financial reporting quality is likely to be more limited. Abnormal accruals also tend to have high levels of measurement error and even bias (DeFond and Zhang 2014).

To measure abnormal accruals, we construct a variable $\left|D A_{j t}\right|$, which is the absolute value of the residual from the following modified cross-sectional Jones (1991) model with an intercept, as suggested by Kothari et al. (2005):

$$
T A C_{j t} / T A_{j t-1}=\alpha_{0}+\alpha_{1}\left(1 / T A_{j t-1}\right)+\alpha_{2}\left(\left(\Delta R E V_{j t}-\Delta R E C_{j t}\right) / T A_{j t-1}\right)+\alpha_{3}\left(P P E_{j t} / T A_{j t-1}\right)+\varepsilon_{j t},
$$

where $j$ denotes the client and $t$ denotes the year. The variables in Model (1) are defined as follows: $T A C_{j t}$ is the total accruals for client $j$ in year $t$ (measured as the change in accounts receivable plus the change in inventory plus the change in accrued assets minus the change in accounts payable minus the change in accrued liabilities minus depreciation and amortization expense), $\triangle R E V_{j t}$ is the change in revenues for client $j$ in year $t, \Delta R E C_{j t}$ is the change in net accounts receivable for client $j$ on year $t, P P E_{j t}$ is property, plant, and equipment for client $j$ in year $t$, and $T A_{j t-1}$ is the total assets for client $j$ in year $t-1$. We estimate Model (1) for each twodigit SIC industry-year with at least 30 client-year observations.

IQ score

An audit partner's cognitive ability measure (IQ score) is obtained from psychometric tests administrated by the Swedish Armed Forces. Military service in Sweden was compulsory until 2010. According to the Swedish Act on Liability for Total Defense Service, all males with Swedish citizenship had to attend the enlistment test at around the age of 18 . The 
enlistment procedure spanned two days involving tests of medical status, physical fitness, cognitive ability, and an interview with a psychologist. The enlistment procedure aimed at estimating an individual's ability to fulfill military services and choosing suitable individuals for different services. The test of cognitive ability consisted of four different subtests (logical, verbal, spatial, and technical), which were graded on a scale from one to nine. The results of these tests were then transformed to a discrete variable of general cognitive ability that also ranges from one (low ability) to nine (high ability) with an average of five, which corresponds to an IQ score of about 100. Carlstedt (2000) and Beauchamp et al. (2017) discuss the history of psychometric testing in the Swedish Armed Forces and provide evidence that the measure of cognitive ability is a good measure of general intelligence (Spearman 1904). ${ }^{9}$ Deary (2001) also reports that IQ scores from cognitive-ability tests have validity that is almost unequaled in psychology.

To measure an audit partner's IQ, we construct a variable $I Q_{i}$, which is equal to an audit partner's IQ score ranging from one (the lowest IQ) to nine (the highest IQ). In untabulated analyses, we have re-estimated all our regression models by excluding audit partners with very low IQ scores (IQ scores lower than four) and obtain results that are similar to those reported in this paper, with one exception. Namely, the estimated coefficient for the variable $I Q_{i}$ is insignificant in the income-decreasing abnormal accruals regression reported in column 3 of Table 8.

\section{Control variables}

9 The measure is similar to the Armed Forces Qualifications Test score (AFQT) used in the US, which measures the aptitude and trainability of individuals eligible for enlistment. The four areas used to compute the AFQT score are word knowledge, paragraph comprehension, arithmetic reasoning, and mathematics knowledge. The AFQT score is frequently employed as a general indicator of cognitive skills and learning aptitude (Levine and Rubinstein 2017). 
Auditor-specific variables. We include in our empirical analyses various auditor-specific variables to control for auditor characteristics that are likely to affect audit quality as measured by going-concern reporting accuracy, audit fees, and abnormal accruals. First, we control for an auditor's reputational capital with the variable PROPLISTCL $L_{i t}$, which is equal to the proportion of publicly listed clients of an audit partner (Moizer 1997). We expect that partners with more listed clients have stronger incentives to provide better audit quality because of their greater reputational capital concerns. ${ }^{10}$ We also control for auditor industry specialization with the dummy variable $I N D S P E C_{i t}$, which is equal to one if an audit partner has been classified as a specialist, i.e. the audit partner's audited assets for a given industry belong to the highest quartile of its distribution, and zero otherwise (Balsam et al. 2003; Bedard and Biggs 1991; Krishnan 2003; and Zerni 2012). We expect an audit partner's industry specialization to improve audit quality. Following Sundgren and Svanström (2014), we control for the length of an auditor's career $\left(\ln \left(1+C A R E E R_{i t}\right)\right)$ and the number of clients $\left(\ln \left(1+N A U D I T S_{i t}\right)\right)$, but do not have specific predictions for these variables. We further control for an auditor's risk preferences by including the dummy variable $C R I M E_{i}$, which is equal to one if an audit partner has been convicted or suspected of a crime, and zero otherwise. We expect that audit partners who have been convicted or suspected of a crime charge higher audit fees and allow their clients more discretion in financial reporting (Amir et al. 2014), but we do not have a specific prediction for the variable $C R I M E_{i}$ in the going-concern reporting accuracy analyses. Finally, we control for the length of auditor tenure $\left(\ln \left(1+T E N U R E_{i j t}\right)\right)$ (DeAngelo 1981; Knechel and Vanstraelen 2007; and Johnson et al. 2002) and the relative size of the client (INFLUENCE $E_{i j t}$ ) (Francis and Yu 2009; Li 2009; and Ye et al. 2011). We

\footnotetext{
10 A similar but opposite phenomenon called the contagion effect has been reported both at the audit partner level (Li et al. 2017) and office level (Francis and Michas 2013).
} 
expect the relative size of the client to decrease audit quality, but do not have a prediction for the length of auditor tenure.

Client-specific variables. Following previous studies (Balsam et al. 2003; Becker et al. 1998; Francis and Yu 2009; Frankel et al. 2002; Johnson et al. 2002; Myers et al. 2003; and Reichelt and Wang 2010), we include in our empirical analyses a set of control variables for client characteristics that are likely to affect audit quality. We include the natural logarithm of total assets $\left(\ln \left(S I Z E_{j t}\right)\right)$ and client age $\left(\ln \left(C L I E N T A G E_{j t}\right)\right)($ Becker et al. 1998; Myers et al. 2003). To control for financial leverage and liquidity (Balsam et al. 2003; Becker et al. 1998; Francis and Yu 2009; and Reichelt and Wang 2010), we include the ratio of total debt to total assets $\left(L E V E R A G E_{j t}\right)$, the ratio of current assets to current liabilities $\left(C U R R E N T_{j t}\right)$, the interest coverage ratio $\left(\ln \left(1+C O V E R A G E_{j t}\right)\right)$, and the probability of financial distress based on Shumway's (2001) estimates of Zmijewski's (1984) financial distress prediction model $\left(\ln \left(P R O B Z_{j t}\right)\right)$. We further include the ratio of inventory to total assets $\left(I N V E N T_{j t}\right)$ since this account requires extensive auditor judgment (Hay et al. 2006; Simunic 1980). We control for accounting performance including a continuous measure of profitability $\left(R O A_{j t}\right)$, and the incidence of losses with a dummy variable for negative net income $\left(\operatorname{LOSS}_{j t}\right)$ (Francis and $\mathrm{Yu}$ 2009). In the going-concern reporting accuracy and abnormal accruals analyses, we include a dummy variable for publicly listed clients $\left(L I S T E D_{j t}\right)$. In the going-concern reporting accuracy analyses, we further include a dummy variable if the client's total equity is less than half of the common stock $\left(E Q \_H A L F_{j t}\right)$, and a dummy if the client is a subsidiary of another company $\left(S U B S I D_{j t}\right)($ Knechel et al. 2015). In the audit fee analyses, we include a dummy if the client is audited by two audit firms (JOINTAUDIT $\left.T_{j t}\right)$, the proportion of sales generated by foreign operations (FOREIGNSALES $S_{j t}$ ), a dummy variable for exceptional or extraordinary items $\left(\right.$ EXCEPTION $\left._{j t}\right)$, and price-to-book ratio $\left(P B_{j t}\right)$ (Hay et al. 2006; Zerni 2012). 
Finally, we include in all our empirical analyses year (YEAR_y), industry (2-digit SIC) $\left(I N D \_s_{j}\right)$, credit rating $\left(C R E D I T R A T E \_s_{j}\right)$, and audit firm $\left(A U D I T F I R M_{-} s_{j}\right)$ fixed effects. In the audit fee and abnormal accruals analyses, we also report results including client fixed effects $\left(C L I E N T_{-} s_{j}\right)$ instead of industry fixed effects. Because the IQ score of a given audit partner is time-invariant, these results are based on a reduced sample that excludes clients that have not changed their audit partner during the sample period. We do not include client fixed effects in the going-concern reporting accuracy analyses because of the binary nature of the dependent variables (Knechel et al. 2015). Because of the lack of a sufficient number of observations for non-Big $\mathrm{N}$ audit firms, we include dummy variables for each of the Big $\mathrm{N}$ audit firms and combine non-Big $\mathrm{N}$ audit firms into one dummy variable. All variables are defined in the Appendix.

\section{Model specifications}

To examine the association between an audit partner's IQ and going-concern reporting accuracy, we estimate the following logistic regression model separately for Total reporting error, Type 1 reporting error, and Type 2 reporting error: ${ }^{11}$

$$
\operatorname{Pr}\left(G C_{-} E R R O R_{j t}=1\right)=F\left(\alpha+\beta I Q_{i}+\gamma^{\prime} \boldsymbol{X}+\text { Fixed effects }+\varepsilon_{j t}\right)
$$

where $i$ denotes the audit partner, $j$ denotes the client, and $t$ denotes the year. The dependent variable, GC_ERROR $R_{j t}$, is either a dummy variable for Total reporting error $\left(T O T A L \_E R R O R_{j t}\right)$, Type 1 reporting error $\left(T Y P E_{-}{ }_{1} \_E R R O R_{j t}\right)$, or Type 2 reporting error $\left(T Y P E 2 \_E R R O R_{j t}\right)$. The vector $\boldsymbol{X}$ includes a comprehensive set of both auditor- and client-

\footnotetext{
${ }^{11}$ We have repeated all our logistic regression analyses using Firth's (1993) penalized maximum likelihood estimation method, which is a method to analyze rare events with logistic regression similar to the method in King and Zeng (2001). The untabulated results of these regressions are similar to those reported in the paper.
} 
specific control variables. The model also includes year, industry (2-digit SIC code), credit rating, and audit firm fixed effects. All coefficient $z$-statistics are reported using robust standard errors clustered at the client level in Total error and Type 1 error analyses and at the audit firm level in Type 2 error analysis. ${ }^{12}$ All variables in Model (2) are as described above and in the Appendix.

We estimate the following OLS regression model to examine the association between an audit partner's IQ and audit fees: ${ }^{13}$

$$
\ln \left(A U D I T F E E S_{j t}\right)=\alpha+\beta I Q_{i}+\gamma^{\prime} \boldsymbol{X}+\text { Fixed effects }+\varepsilon_{j t}
$$

where $i$ denotes the audit partner, $j$ denotes the client, and $t$ denotes the year. All variables in Model (3) are as described above and in the Appendix. The vector $\boldsymbol{X}$ includes a set of auditorand client-specific control variables. The model also includes year, industry (2-digit SIC code) (or alternatively, client), credit rating, and audit firm fixed effects. All coefficient $t$-statistics are reported using robust standard errors clustered at the client level.

To test the association between an audit partner's IQ and abnormal accruals of the client, we estimate the following OLS regression model for all abnormal accruals and separately for positive (income-increasing) and negative (income-decreasing) abnormal accruals:

$$
\left|D A_{j t}\right|=\alpha+\beta I Q_{i}+\gamma^{\prime} \boldsymbol{X}+\text { Fixed effects }+\varepsilon_{j t},
$$

where $i$ denotes the audit partner, $j$ denotes the client, and $t$ denotes the year. The vector $\boldsymbol{X}$ includes a comprehensive set of auditor- and client-specific control variables. The model also

12 In Type 2 error analysis, we cluster standard errors at the audit firm level rather than at the client level because there is only one observation for each client in this analysis.

13 We estimate Model (3) using publicly listed companies only, because audit fee data is not readily available in any database for Swedish privately held companies. If multiple partners are involved in auditing a listed client, we calculate the average IQ of all the audit partners involved in that audit engagement (see Amir et al. 2014). 
includes year, industry (2-digit SIC code) (or alternatively, client), credit rating, and audit firm fixed effects. All coefficient $t$-statistics are reported using robust standard errors clustered at the client level.

\section{Results}

\section{Descriptive statistics}

We report audit partners' IQ score distribution in Figure 1 and audit partners' characteristics in Table 1. Panel A of Table 1 reports descriptive statistics for the variables that capture audit partners' personal characteristics. The mean value of audit partners' IQ equals 6.8 , which is clearly higher than the mean value of 5.0 in the rest of the population. This is not surprising, since audit partners must have a master's degree in accounting, must have passed a challenging CPA exam, and it is also likely that only the most capable auditors are invited as partners. Although a majority of the audit partners have an IQ score that is higher than the population average, there is also substantial variation in their IQ. The average audit partner in the sample received CPA certification 17.9 years ago $\left(C A R E E R_{i t}\right)$ and has 67.7 clients, including both privately held and publicly listed clients $\left(N A U D I T S_{i t}\right)$. Roughly, one third of the audit partners are industry specialists $\left(I N D S P E C_{i t}\right)$, and 16.1 percent have been convicted or suspected of a crime $\left(C R I M E_{i}\right)$. Private clients clearly dominate listed clients in the auditors' client portfolio (PROPLISTCL $L_{i t}$ ). Finally, 73.2 percent of the audit partners work in Big N audit firms $\left(B I G N_{i t}\right)$.

Panel B of Table 1 reports the mean values of the auditor characteristics for different levels of an audit partner's IQ. As for the dummy variables INDSPEC $i t, C R I M E_{i}$ and $B I G N_{i t}$, the numbers reported in the table show, for each level of the audit partners' IQ, the proportions of industry specialist, criminally convicted and Big $\mathrm{N}$ audit firm partners, respectively. These results show that the audit partners with the highest IQ score have significantly fewer criminal 
convictions and have significantly more listed clients than the audit partners with the lowest IQ score. The other variables that capture auditor characteristics do not exhibit any significant differences between the lowest- and highest-IQ audit partners. For example, the results show that the proportion of Big $\mathrm{N}$ auditors is not significantly different between the lowest- and highest-IQ audit partners.

(Insert Figure 1 about here)

(Insert Table 1 about here)

Table 2 reports descriptive statistics for the variables used in the analyses of goingconcern reporting accuracy (panel A), audit fee (panel B), and abnormal accruals (panel C). Panel A of Table 2 shows that Type 1 reporting errors are quite rare events ( 0.5 percent), compared to Type 2 reporting errors (78.6 percent). This suggests that the threshold for issuing a going-concern audit report in Sweden is very high, compared to the more litigious auditing environment in the US (Francis 2004). The proportions of both Type 1 and Type 2 reporting errors are similar to those reported in previous studies using data from Sweden (Sundgren and Svanström 2014). Untabulated Spearman correlations between the independent variables in Models (2) - (4) were generally low, with few exceptions. We have re-estimated Models (2) - (4) after excluding all independent variables with correlation coefficients greater than 0.5 with another independent variable, and the results were similar to those reported in the paper.

(Insert Table 2 about here) 
Table 3 reports the results of the univariate analysis of exploring the association between audit partners' IQ and going-concern reporting accuracy. Specifically, we test whether the mean IQ scores are significantly different between those audit partners who have issued an incorrect going-concern audit report and those who have not issued such a report. Panel A of Table 3 reports the results for the full sample and panel B reports the results for a reduced sample, which excludes clients in extreme financial distress, defined as those that belong to the $10^{\text {th }}$ decile of the variable $P R O B Z_{j t}$. We report the results for this reduced sample because clients in extreme financial distress are very likely to fail, and consequently, while there may be some room for judgment, the auditor often has no choice but to issue a going-concern audit report.

The results reported in Table 3 show that the IQ of an average audit partner who has issued an incorrect going-concern audit report is significantly lower than that of an audit partner who has not issued such a report, suggesting that audit partners' IQ is associated with improved going-concern reporting accuracy. This result holds for all three reporting error types; i.e., Total, Type 1, and Type 2 reporting errors. The results for the full sample and the reduced sample are similar.

(Insert Table 3 about here)

Table 4 reports the results of estimating the going-concern reporting accuracy model (Model 2) for both the full sample and the reduced sample separately for Total reporting error (column 1) and Type 1 (column 2) and Type 2 (column 3) reporting errors. The results show that the estimated coefficients for $I Q_{i}$ are significantly negative for all three reporting error types, with the exception of Type 2 reporting error for the full sample. These results suggest 
that, after controlling for relevant auditor and client characteristics, going-concern reporting accuracy increases with an audit partner's IQ. ${ }^{14}$

The results for the control variables in Table 4 show that the estimated coefficients for the auditor-specific control variables are generally insignificant. As for the client-specific control variables, Total reporting errors are more likely to occur when the client is $\operatorname{larger}\left(\ln \left(S I Z E_{j t}\right)\right)$, more financially leveraged $\left(L E V E R A G E_{j t}\right)$, has lower interest coverage ratio $\left(\ln \left(1+C O V E R A G E_{j t}\right)\right)$ or probability of financial distress $\left(\ln \left(P R O B Z_{j t}\right)\right)$, equity capital lower than half of share capital $\left(E Q \_H A L F_{j t}\right)$, less inventory $\left(I N V E N T_{j t}\right)$, or weaker accounting performance $\left(R O A_{j t}\right.$ and $\left.L O S S_{j t}\right)$

We next provide insight into the economic significance of these results by calculating marginal changes in the probability that an audit partner issues an incorrect going-concern audit report as a result of changing the levels of the explanatory variables in Model (2). The marginal effects show the marginal changes in the probability for a unit increase in each explanatory variable while holding the other explanatory variables at their mean values. In Table 4 , the untabulated marginal effects of $I Q_{i}$ for the full sample (reduced sample) are -0.10 $(-0.05),-0.05(-0.05)$, and $-0.9(-1.3)$ percent for Total error, Type 1 error, and Type 2 error, respectively. The untabulated odds ratios for the variable IQ using the full sample (reduced sample) are $0.911(0.878), 0.915$ (0.868), and $0.903(0.878)$ for Total error, Type 1 error, and Type 2 error, respectively.

\footnotetext{
${ }^{14}$ We have also repeated the univariate and multivariate analyses presented in Tables 3 and 4 for the Type 2 reporting error by using a two-year-ahead (24-month) failure period instead of a one-year-ahead (12-month) failure period. The untabulated results of these analyses show that an audit partner's IQ is significantly positively associated with going-concern reporting accuracy for Total and Type 1 errors for the full and reduced samples, but that there is no significant association between an audit partner's IQ and Type 2 errors. The weaker results for Type 2 error are most likely due to the fact that in Sweden the auditor's task is to evaluate whether there are material uncertainties about the company's ability to continue as a going-concern for a time span of typically 12 months from the fiscal year end (RS 570, $\S 18)$.
} 
(Insert Table 4 about here)

\section{Audit partner's IQ and audit fees}

Table 5 reports the results of the univariate analysis of examining the association between audit partners' IQ and audit fees (in million SEK). Specifically, we first sort audit fees into quartiles, where Quartile 1 (Quartile 4) includes the lowest (highest) fees, and then calculate the mean IQ score of audit partners in each fee quartile. Column 1 reports the results for the full sample and column 2 reports the results for the reduced sample, which excludes clients that have not changed their audit partner during the sample period. We report the results for the reduced sample because excluding clients that have not changed their audit partner during the sample period allows us to include client fixed effects in the regression model. The results reported in Table 5 show that audit partners' mean IQ score increases monotonically across the audit fee quartiles. The mean IQ score is 6.58 (6.60) in Quartile 1 for the full (reduced) sample and 7.16 (7.15) in Quartile 4 for the full (reduced) sample, the difference being statistically significant at the 1 percent level.

(Insert Table 5 about here)

Table 6 reports the results of estimating the audit fee model (Model 3) for both the full sample (column 1) and the reduced sample including client fixed effects (column 2). These results show that the estimated coefficient of $I Q_{i}$ is significantly positive both in the full sample and in the reduced sample, thereby providing consistent evidence that clients are willing to pay a fee premium for audit services of high-IQ audit partners. This effect is economically significant, as a one-unit increase in an audit partner's IQ increases audit fees by 6.61 (5.23) percent for the full sample (reduced sample), holding the control variables constant at their 
mean values. The explanatory power of both model specifications reported in Table 6 is comparable to that reported in previous studies, and the signs of the coefficients for the control variables are as expected. The results for the auditor-specific control variables show that clients of audit partners with criminal convictions $\left(C R I M E_{i}\right)$ pay higher fees, and influential clients pay lower fees. As for the client-specific control variables, the estimated coefficients of $\ln \left(S I Z E_{j t}\right)$ and EXCEPTION $N_{j t}$ are significantly positive, and those of CURRENT $T_{j t}$ and $\ln \left(1+C O V E R A G E_{j t}\right)$ are significantly negative for both the full sample and the reduced sample. The rest of the control variables do not exhibit any consistently significant relation to audit fees.

(Insert Table 6 about here)

\section{Audit partner's IQ and abnormal accruals}

Table 7 reports the results of the univariate analysis of exploring the association between audit partners' IQ and abnormal accruals. Specifically, we first divide both the full sample and the reduced sample, which excludes clients that have not changed their audit partner during the sample period, into five quintiles based on the absolute value of abnormal accruals (the variable $\left.\left|D A_{j t}\right|\right)$, where Quintile 1 (Quintile 5) includes the lowest (highest) abnormal accruals. We then calculate audit partners' mean IQ score in each abnormal accruals quintile. Column 1 reports the results for the absolute value of abnormal accruals when both income-increasing and income-decreasing abnormal accruals are included. Columns 2 and 3 report the results for the absolute values of income-increasing and income-decreasing abnormal accruals, respectively.

The results reported in Table 7 show that, for the full sample of income-increasing abnormal accruals, audit partners' mean IQ score decreases from Quintile 1 to Quintile 5, the 
average IQ scores being significantly different at the 10 percent level. However, this result does not hold for the reduced sample. We do not observe any statistically significant differences in audit partners' average IQ between the abnormal accruals quintile groups when both income-increasing and income-decreasing abnormal accruals are included or when only income-decreasing abnormal accruals are included.

(Insert Table 7 about here)

Table 8 reports the results of estimating the abnormal accruals model (Model 4) for both the full sample and the reduced sample, including client fixed effects. These results show that the estimated coefficient of $I Q_{i}$ is significantly negative for the absolute value of incomeincreasing accruals in the full sample, but it is insignificant in the reduced sample. The estimated coefficient of $I Q_{i}$ for the absolute value of income-decreasing abnormal accruals is significantly positive in the full sample but insignificant in the reduced sample. The significantly positive coefficient of IQ for the absolute value of income-decreasing accruals is consistent with Lennox, Wu, and Zhang (2016) who find that audit adjustments result in smaller income-increasing and larger income-decreasing accruals and that these adjustments help to increase earnings quality. The estimated coefficient of $I Q_{i}$ is not significant for the absolute value of abnormal accruals when both income-increasing and income-decreasing abnormal accruals are included. All the auditor- and client-specific control variables in Table 8 are generally significantly related to the absolute value of abnormal accruals when both income-increasing and income-decreasing abnormal accruals are included or when only income-increasing or income-decreasing abnormal accruals are included.

In sum, we find some evidence that auditors' IQ scores are negatively associated with income-increasing earnings management of their client. We find only very weak evidence that 
auditors' IQ is associated with clients' income-decreasing earnings management. However, given that these results only hold in the full sample of clients, and not in the reduced sample, these results should be interpreted as suggestive. Economic significance of these results is also weak, as a one-unit increase in an audit partner's IQ decreases (increases) the absolute value of income-increasing accruals by only $0.2(0.1)$ percent for the full sample, holding the control variables constant at their mean values.

(Insert Table 8 about here)

\section{Conclusions}

A recent boom in archival research on individual audit partners has been motivated by limitations with using an entire audit firm as the unit of analysis (Lennox and $\mathrm{Wu} 2018$ ). Our paper contributes to this emerging literature by exploring whether an audit partner's cognitive ability (IQ) is related to audit quality. Although experimental research suggests that cognitive ability plays an important role in judgment and decision making in the audit process (Bonner and Lewis 1990; Gibbins 1984; and Nelson and Tan 2005), it is not obvious that an auditor's cognitive ability matters for audit quality. In particular, audit regulation and audit firms' own control and risk mechanisms and knowledge sharing systems may result in the standardization of audits and thus reduce variation in the quality of audits. Audits are, moreover, conducted by teams, not by individuals. Experiments do not usually take into account firm-level quality control systems or the fact that audits are conducted by a group of individuals, and consequently, the question remains whether differences in auditors' cognitive ability could explain the documented variation in the quality of audit services within the same audit firm.

To the best of our knowledge, this is the first archival study on the role of auditors' cognitive ability in the quality of audit services. Using Swedish audit partners' IQ scores from 
psychological tests combined with data on their complete client portfolios, we show that an audit partner's IQ is positively related to going-concern reporting accuracy. We also find that an audit partner's IQ is positively related to audit fees, suggesting that clients are willing to pay a fee premium for the audit services of smarter audit partners. Finally, we find some, albeit weak, evidence that an audit partner's IQ is negatively related to the income-increasing abnormal accruals of the client.

This study is subject to limitations. First, audit quality is a complex concept involving many dimensions that must be measured by using proxies that contain measurement error. In an attempt to triangulate our findings, we use several proxies that capture different dimensions of audit quality. Second, the use of archival data raises endogeneity concerns. In particular, an audit partner's IQ could proxy for correlated omitted variables, or the direction of causation could run from clients with higher audit quality to the use of more capable auditors. Third, data availability issues impose some limitations on the analyses because audit fees are not readily available for Swedish privately held companies.

This study provides an important and interesting insight into the nature of audit services. We show that, in spite of the various mechanisms that aim to standardize audit quality, the intellectual ability of the audit partner still matters for the quality of the audit services delivered to the client. Therefore, these findings may be of interest to those developing and making decisions on mechanisms that control and regulate the quality of audit services. 
APPENDIX. Variable definitions

\begin{tabular}{|c|c|c|}
\hline Variable & Description & Data Source \\
\hline \multicolumn{3}{|c|}{ Panel A: Audit quality proxies } \\
\hline$T Y P E \_1 \_E R R O R R_{j t}$ & $\begin{array}{l}\text { Dummy variable equal to one if an audit partner issues a going-concern audit report } \\
\text { to a client that subsequently does not file for bankruptcy within } 12 \text { months of the } \\
\text { audit partner's report, and zero otherwise. }\end{array}$ & $\mathrm{UC} \mathrm{AB}$ \\
\hline$T Y P E \_2 \_E R R O R R_{j t}$ & $\begin{array}{l}\text { Dummy variable equal to one if an audit partner does not issue a going-concern audit } \\
\text { report to a client that subsequently files for bankruptcy within } 12 \text { months of the audit } \\
\text { partner's report, and zero otherwise. }\end{array}$ & $\mathrm{UC} \mathrm{AB}$ \\
\hline TOTAL_ERROR $R_{j t}$ & $\begin{array}{l}\text { Dummy variable equal to one if } T Y P E \_1 \_E R R O R \text { or } T Y P E \_2 \_E R R O R \text { equals one, } \\
\text { and zero otherwise. }\end{array}$ & $\mathrm{UC} \mathrm{AB}$ \\
\hline $\ln \left(A U D I T F E E S_{j t}\right)$ & The natural logarithm of audit fees. Audit fees are stated in SEK. & Compustat Global Vantage \\
\hline$D A_{j t}$ & $\begin{array}{l}\text { Abnormal accruals of a client, defined as the residual from the modified cross- } \\
\text { sectional Jones (1991) model estimated with an intercept (Kothari et al. 2005). }\end{array}$ & $\mathrm{UC} \mathrm{AB}$ \\
\hline$\left|D A_{j t}\right|$ & The absolute value of the variable $D A$. & $\mathrm{UC} \mathrm{AB}$ \\
\hline \multicolumn{3}{|c|}{ Panel B: Audit partner's IQ } \\
\hline$I Q_{i}$ & Audit partners' IQ score ranging from one (the lowest IQ) to nine (the highest IQ). & The Swedish Armed Forces \\
\hline \multicolumn{3}{|c|}{ Panel C: Auditor-specific control variables } \\
\hline PROPLISTCL $L_{i t}$ & The proportion of publicly listed clients of an audit partner. & $\begin{array}{l}\text { UC AB; Compustat Global } \\
\text { Vantage }\end{array}$ \\
\hline$I_{N D S P E C} C_{i t}$ & $\begin{array}{l}\text { Dummy variable equal to one if an audit partner is classified as an industry specialist } \\
\text { according to the criteria that the audit partner's audited assets for a given industry } \\
\text { belong to the highest quartile of its distribution, and zero otherwise. }\end{array}$ & $\begin{array}{l}\text { UC AB; Compustat Global } \\
\text { Vantage }\end{array}$ \\
\hline
\end{tabular}




\section{$\ln \left(1+\right.$ CAREER $\left._{i t}\right)$}

$\ln \left(1+N A U D I T S_{i t}\right)$

CRIME $_{i}$

$\ln \left(1+T E N U R E_{i j t}\right)$

INFLUENCE $E_{i j t}$

$B I G N_{i t}$
The natural logarithm of one plus the number of years since an audit partner received professional certification.

The natural logarithm of one plus the total number of clients of an audit partner.

Dummy variable equal to one if an audit partner has been convicted or suspected of a crime, and zero otherwise.

The natural logarithm of one plus the number of years an audit partner has audited a client.

The natural logarithm of the proportion of a client's sales of the sales of all clients of an audit partner.

Dummy variable equal to one if an audit partner works for one of the Big $\mathrm{N}$ firms (PWC, Deloitte, KPMG, Ernst \&Young, or Arthur Andersen), and zero otherwise.

Panel D: Client-specific control variables
The natural logarithm of total assets of a client. Total assets are stated in SEK.

$\ln \left(\right.$ CLIENTAGE $\left._{j t}\right) \quad$ The age of a client.

LEVERAGE $_{j t} \quad$ The ratio of total debt to total assets of a client.

CURRENT $_{j t} \quad$ The ratio of current assets to current liabilities of a client.

$\ln \left(1+\right.$ COVERAGE $\left.E_{j t}\right) \quad$ The natural logarithm of one plus the interest coverage ratio of a client.
Professional Institute for Certified Auditors and other Accounting Professionals

UC AB; Compustat Global Vantage

The Swedish National Council for Crime Prevention; The Swedish National Police Board

Professional Institute for Certified Auditors and other Accounting Professionals

UC AB; Compustat Global Vantage

Professional Institute for Certified Auditors and other Accounting Professionals

UC AB; Compustat Global

Vantage

UC AB; Compustat Global Vantage

UC AB; Compustat Global

Vantage

UC AB; Compustat Global

Vantage

UC AB; Compustat Global

Vantage 


\begin{tabular}{|c|c|c|}
\hline $\ln \left(P R O B Z_{j t}\right)$ & $\begin{array}{l}\text { The natural logarithm of the probability of financial distress of a client based on } \\
\text { Shumway's (2001) estimates of Zmijewski's (1984) financial distress prediction } \\
\text { model }\end{array}$ & $\begin{array}{l}\text { UC AB; Compustat Global } \\
\text { Vantage }\end{array}$ \\
\hline$I N V E N T_{j t}$ & The ratio of inventory to total assets of a client. & $\begin{array}{l}\text { UC AB; Compustat Global } \\
\text { Vantage }\end{array}$ \\
\hline$R O A_{j t}$ & The return on assets ratio of a client. & $\begin{array}{l}\text { UC AB; Compustat Global } \\
\text { Vantage }\end{array}$ \\
\hline$L O S S_{j t}$ & Dummy variable equal to one if a client' net income is negative, and zero otherwise. & $\begin{array}{l}\text { UC AB; Compustat Global } \\
\text { Vantage }\end{array}$ \\
\hline$E Q \_H A L F_{j t}$ & $\begin{array}{l}\text { Dummy variable equal to one if a client's total equity is less than half of the common } \\
\text { stock, and zero otherwise. }\end{array}$ & $\mathrm{UC} \mathrm{AB}$ \\
\hline$S U B S I D_{j t}$ & $\begin{array}{l}\text { Dummy variable equal to one if a client is a subsidiary of another company, and zero } \\
\text { otherwise. }\end{array}$ & $\mathrm{UC} \mathrm{AB}$ \\
\hline LISTED $_{j t}$ & Dummy variable equal to one if a client is publicly listed, and zero otherwise. & $\begin{array}{l}\text { UC AB; Compustat Global } \\
\text { Vantage }\end{array}$ \\
\hline JOINTAUDIT $_{j t}$ & $\begin{array}{l}\text { Dummy variable equal to one if a client is audited by two audit firms, and zero } \\
\text { otherwise. }\end{array}$ & $\begin{array}{l}\text { UC AB; Compustat Global } \\
\text { Vantage }\end{array}$ \\
\hline FOREIGNSALES $_{j t}$ & The proportion of a client's sales generated by foreign operations. & Compustat Global Vantage \\
\hline$E X E P T I O N_{j t}$ & $\begin{array}{l}\text { Dummy variable equal to one if a client reports exceptional or extraordinary items, } \\
\text { and zero otherwise. }\end{array}$ & Compustat Global Vantage \\
\hline$P B_{j t}$ & A client's price-to-book ratio. & Compustat Global Vantage \\
\hline$Y E A R \_y$ & The nine yearly dummy variables for the years 2000 to 2008 . & $\begin{array}{l}\text { UC AB; Compustat Global } \\
\text { Vantage }\end{array}$ \\
\hline CLIENT_s $s_{j}$ & Dummy variables for each client. & $\begin{array}{l}\text { UC AB; Compustat Global } \\
\text { Vantage }\end{array}$ \\
\hline$I N D \_s_{j}$ & Dummy variables for each industry (2-digit SIC). & $\begin{array}{l}\text { UC AB; Compustat Global } \\
\text { Vantage }\end{array}$ \\
\hline
\end{tabular}


AUDITFIRM_s $s_{j}$

CREDITRATE_s
Dummy variables for different audit firms. We include dummy variables for each of the Big $\mathrm{N}$ firms and combine non-Big $\mathrm{N}$ audit firms into one dummy variable because of the lack of sufficient number of observations for non-Big $\mathrm{N}$ firms.

UC AB; Compustat Global Vantage

The four dummy variables for the credit ratings from one to four (five being the reference group) issued for a client by the credit rating agency UC AB.
$\mathrm{UC} A B$ 


\section{References}

Abdolmohammadi, M.J., and U.J. Shanteau. 1992. Personal attributes of expert auditors. Organizational Behavior and Human Decision Processes 53: 158-172.

Adams, R., M. Keloharju, and S. Knupfer. 2015. Are CEOs born leaders? Lessons from traits of a million individuals. Working paper, Harvard Business School.

Amir, E., Kallunki, J.P., and H. Nilsson. 2014. The association between individual audit partners' risk preferences and the composition of their client portfolios. Review of Accounting Studies 19: 103-133.

Aobdia, D., C.J. Lin, and R. Petacchi. 2015. Capital market consequences of audit partner quality. The Accounting Review 90: 2143-2176.

Balsam, S., J. Krishnan, and J.S. Yang. 2003. Auditor industry specialization and earnings quality. Auditing: A Journal of Practice \& Theory 22: 71-97.

Beauchamp, J., D. Cesarini, and M. Johannesson. 2017. The psychometric and empirical properties of measures of risk preferences. Journal of Risk and Uncertainty 54: 203-237.

Becker, C., M. DeFond, J. Jiambalvo, and K.R. Subramanyam. 1998. The effect of audit quality on earnings management. Contemporary Accounting Research 15: 1-24.

Bedard, J.C., and S. Biggs. 1991. The effect of domain-specific experience on evaluation of management representations in analytical procedures. Auditing: A Journal of Practice and Theory 10: 77-90.

Bedard, J.C., D.R. Deis, M.B. Curtis, and J.G. Jenkins. 2008. Risk monitoring and control in audit firms: A research synthesis. Auditing: A Journal of Practice and Theory 27: 187-218.

Bonner, S.E., and B.L. Lewis. 1990. Determinants of auditor expertise. Journal of Accounting Research 28: 1-20.

Borghans, L., A.L. Duckworth, J.J. Heckman, and B. Ter Weel. 2008. The economics and psychology of personality traits. Journal of Human Resources 43: 972-1059.

Burrows, G., and C. Black. 1998. Profit sharing in Australian Big 6 accounting firms: An exploratory study. Accounting, Organizations, and Society 23: 517-530.

Cameran, M., D. Campa, and J.R. Francis 2017. How important is partner variation in explaining audit quality? Working paper, European Accounting Association, May 2017, Valencia, Spain.

Caramanis, C., and C. Lennox. 2008. Audit effort and earnings management. Journal of Accounting and Economics 45: 116-138.

Carey, P., and R. Simnett. 2006. Audit partner tenure and audit quality. The Accounting Review 81: 653-676. 
Carlstedt, B. 2000. Cognitive abilities: Aspects of Structure, Process and Measurement. Gothenburg University (PhD dissertation), Gothenburg.

Chen, S., S.Y. Sun, and D. Wu. 2010. Client importance, institutional improvements, and audit quality in China: An office and individual auditor level analysis. The Accounting Review 85: $127-158$.

Chi, H.Y., and C.L. Chin. 2011. Firm versus partner measures of auditor industry expertise and effects on auditor quality. Auditing: A Journal of Practice \& Theory 30: 201-229.

Chin, C., and H. Chi. 2009. Reducing restatements with increased industry expertise. Contemporary Accounting Research 26: 729-765.

Chow, C.W., J.L. Ho, and S.C. Vera-Munõz. 2008. Exploring the extent and determinants of knowledge sharing in audit engagements. Asia-Pacific Journal of Accounting \& Economics 15: $141-160$.

Chu, J., A. Florou, and P. Pope. Does accounting education add value in auditing? Evidence from the UK. Working paper, European Accounting Association, May 2017, Valencia, Spain.

Deary, I.J. 2001. Intelligence: A Very Short Introduction. Oxford University Press.

Dechow, P., W. Ge, and C. Schrand. 2010. Understanding earnings quality: A review of the proxies, their determinants and their consequences. Journal of Accounting and Economics 50: 344-401.

DeAngelo, L.E. 1981. Auditor independence, 'low balling', and disclosure regulation. Journal of Accounting and Economics 3: 113-127.

DeFond, M.L., and J. Zhang. 2014. A review of archival auditing research. Journal of Accounting and Economics 58: 275-326.

Dowling, C. 2009. Appropriate audit support system use: The influence of auditor, audit team, and firm factors. The Accounting Review 84: 771-810.

Emby, C., and M. Favere-Marchesi. 2010. Review partners and engagement partners: The interaction process in engagement quality review. Auditing: A Journal of Practice \& Theory 29: $215-232$.

Epps, K.K., and W.F. Messier. 2007. Engagement quality reviews: A comparison of audit firm practices. Auditing: A Journal of Practice \& Theory 26: 167-181.

Fiolleau, K., K. Hoang, K. Jamal, and S. Sunder. 2010. Engaging auditors: Field investigation of a courtship. Working Paper.

Firth, D. 1993. Bias reduction of maximum likelihood estimates. Biometrika 80: 27-38.

Francis J.R. 2004. What do we know about audit quality? The British Accounting Review 6: 345-368. 
Frankel, R.M., M.F. Johnson, and K.K. Nelson. 2002. The relation between auditors' fees for nonaudit services and earnings management. The Accounting Review 77 (Supplement): 71105.

Francis, J.R., and P.N. Michas. 2013. The contagion effect of low-quality audits. The Accounting Review 88: 521-552.

Francis, J.R., M.L. Pinnuck, and O. Watanabe. 2014. Auditor style and financial statement comparability. The Accounting Review 89: 605-633.

Francis, J.R., and M.D. Yu. 2009. Big 4 office size and audit quality. The Accounting Review 84: $1521-52$.

Gibbins, M. 1984. Propositions about the psychology of professional judgment in public accounting. Journal of Accounting Research 22: 103-125.

Goodwin, J., and D. Wu. 2014. Is the effect of industry expertise on audit pricing an officelevel or a partner-level phenomenon? Review of Accounting Studies 19: 1532-1578.

Griffith, E.E., J.S. Hammersley, and K. Kadous. 2013. Auditing complex estimates: Process, problems, and preliminary recommendations for improving auditor performance. Working Paper.

Grinblatt, M., S. Ikäheimo, M. Keloharju, and S. Knüpfer. 2015. IQ and mutual fund choice. Management Science 62: 924-944.

Grinblatt, M., M. Keloharju, and J.T. Linnainmaa. 2011. IQ and stock market participation. Journal of Finance 66: 2121-2164.

Grinblatt, M., M. Keloharju, and J.T. Linnainmaa. 2012. IQ, trading behavior, and performance. Journal of Financial Economics 104: 339-362.

Gul, F.A., M. Ma, and K.M. Lai. 2017. Busy auditors, partner-client tenure and audit quality: Evidence from an emerging market. Journal of International Accounting Research 16: 83105.

Gul, F.A., D. Wu, and Z. Yang. 2013. Do individual auditors affect audit quality? Evidence from archival data. The Accounting Review 88: 1993-2023.

Hay, D., W.R. Knechel, and N. Wong. 2006. Audit fees: a meta-analysis of the effects of supply and demand attributes. Contemporary Accounting Research 23: 141-191.

Hardies, K., D. Breesch, and J. Branson. 2016. Do (Fe)Male auditors impair audit quality: Evidence from going concern opinions. European Accounting Review 25: 7-34.

Hogarth, R.M. 1991. A perspective on cognitive research in accounting. Accounting Review 66: 277-290.

Huddart, S., and P. Liang. 2003. Accounting in partnerships. American Economic Review 93: 410-14. 
Hunter, J., and F. Hunter. 1984. Validity and utility of alternative predictors of job performance. Psychological Bulletin 96: 72-98.

Hülsheger, U., G. Maier, and T. Stumpp. 2007. Validity of general mental ability for the prediction of job performance and training success in Germany: A meta-analysis. International Journal of Selection and Assessment 15: 3-18.

Ittonen, K., K. Johnstone, and E-R. Myllymäki. 2015. Audit partner public-client specialisation and client abnormal accruals. European Accounting Review 24: 607-633.

Jones, J.J. 1991. Earnings management during import relief investigation. Journal of Accounting Research 29: 193-228.

Johnson, V., I. Khurana, and J.K. Reynolds. 2002. Audit firm tenure and the quality of accounting earnings. Contemporary Accounting Research 19: 637-660.

Keloharju, M., S. Knüpfer, and J. Tåg. 2016. Equal opportunity? Gender gaps in CEO appointments and executive pay. Working Paper. Harvard Business School.

King, G., and L. Zeng. 2001. Logistic regression in rare events data. Political analysis 9: 137-163.

Knechel, W.R. 2000. Behavioral research in auditing and its impact on audit education. Issues in Accounting Education 15: 695-712.

Knechel, W.R., L. Niemi, and M. Zerni. 2013. Empirical evidence on the implicit determinants of compensation in Big 4 audit partnerships. Journal of Accounting Research 51: 349-387.

Knechel, W.R., and A. Vanstraelen. 2007. The relationship between auditor tenure and audit quality implied by going concern opinions. Auditing: A Journal of Practice \& Theory 26: 113 131.

Knechel, W.R., A. Vanstraelen, and M. Zerni. 2015. Does the identity of engagement partners matter? An analysis of audit partner reporting decisions. Contemporary Accounting Research 32: $1443-1478$.

Kothari, S.P., A.J. Leone, and C.E. Wasley. 2005. Performance matched discretionary accruals. Journal of Accounting and Economics 39: 163-197.

Krishnan, G. 2003. Does Big 6 auditor industry expertise constrain earnings management? Accounting Horizon (Supplement): 1-16.

Lemon, W.M., K.W. Tatum, and W.S. Turley. 2000. Developments in the audit methodologies of large accounting firms. London: ABG Professional Information.

Lennox, C. 1999. Are large auditors more accurate than small uditors? Accounting and Business Research 29: 217-227. 
Lennox, C., and X. Wu. 2018. A review of the archival literature on audit partners. Accounting Horizons, forthcoming.

Lennox, C., X. Wu, and T. Zhang. 2016. The effect of audit adjustments on earnings quality: Evidence from China. Journal of Accounting and Economics 61: 545-562.

Levine, R., and Y. Rubinstein. 2017. Smart and illicit: Who becomes an entrepreneur and do they earn more? The Quarterly Journal of Economics 132: 963-1018.

Li, C. 2009. Does client importance affect auditor independence at the office level? Empirical evidence from going-concern opinions. Contemporary Accounting Research 26: 201-230.

Li, L., B. Qi, G. Tian, and G. Zhang. 2017. The contagion effect of low-quality audits at the level of individual auditors. The Accounting Review 92: 137-163.

Libby, R., and H-T. Tan. 1994. Modeling the determinants of audit expertise. Accounting Organizations and Society 19: 701-716.

Libby, R., and J. Luft. 1993. Determinants of judgment performance in accounting settings: Ability, knowledge, motivation, and environment. Accounting, Organizations and Society 18: $425-450$.

Lindqvist, E., and R. Vestman. 2011. Labor market returns to cognitive and noncognitive ability: Evidence from the swedish enlistment. American Economic Journal: Applied Econometrics 3: 101-128.

Lo, C. 2017. Is there a relationship between high IQ scores and positive life outcomes? A critical review. Psychology 8: 627-635.

Mcknight, C.A., and W.F. Wright. 2011. Characteristics of relatively high-performance auditors. Auditing: A Journal of Practice \& Theory 30: 191-206.

Murray, C. 1998. Income inequality and IQ. AEI Press, Washington.

Murthy, U.S., and D.S. Kerr. 2004. Comparing audit team effectiveness via alternative modes of computer-mediated communication. Auditing: A Journal of Practice \& Theory, 23: 141152.

Moizer, P. 1997. Auditor reputation: The international empirical evidence. International Journal of Auditing 1: 61-74.

Myers, J.N., L.A. Myers, and T.C. Omer. 2003. Exploring the term of the auditor-client relationship and the quality of earnings: A case for mandatory auditor rotation? The Accounting Review 78: 779-799.

Myers, L.A., J. Schmidt, and M. Wilkins. 2014. An investigation of recent changes in going concern reporting decisions among Big $\mathrm{N}$ and non-Big $\mathrm{N}$ auditors. Review of Quantitative Finance and Accounting 43: 155-172. 
Neisser, U., G. Boodoo, T.J. Bouchard, W.A. Boykin, N. Brody, and S. Urbina. 1996. Intelligence: knowns and unknowns. American Psychologist 51: 77-101.

Nelson, M., and H-T. Tan. 2005. Judgment and decision making research auditing: A task, person, and interpersonal interaction perspective. Auditing: A Journal of Practice \& Theory 24: 41-71.

Peytcheva, M., and P.R. Gillett. 2011. How partners' views influence auditor judgment. Auditing: A Journal of Practice \& Theory 30: 285-301.

Ramsay, R.J. 1994. Senior/manager differences in audit workpaper review performance. Journal of Accounting Research 32: 127-135.

Reichelt, K.J., and D. Wang. 2010. National and office-specific measures of auditor industry expertise and effects on audit quality. Journal of Accounting Research 48: 647-686.

Rich, J.S., I. Solomon, and K.T. Trotman. 1997. Multi-auditor judgment/decision making research: A decade later. Journal of Accounting Literature 16: 86-126.

Salgado, J.F., N. Anderson, S. Moscoso, C. Bertua, and F. De Fruyt. 2003. International validity generalization of GMA and cognitive abilities: A European community meta-analysis. Personnel Psychology 56: 573-605.

Shumway, T. 2001. Forecasting bankruptcy more accurately: A simple hazard model. The Journal of Business 74: 101-124.

Simnett, R., E. Carson, and A. Vanstraelen. 2016. International archival auditing and assurance research: Trends, methodological issues and opportunities. Auditing: A Journal of Practice and Theory 35: 1-32.

Simunic, D.A. 1980. The pricing of audit services: Theory and evidence. Journal of Accounting Research 18: 161-190.

Sundgren, S., and T. Svanström. 2014. Auditor-in-charge characteristics and going concern reporting. Contemporary Accounting Research 31: 531-550.

Spearman, C. 1904. General intelligence, objectively determined and measured. American Journal of Psychology 15: 201-293.

Tan, H.-T., and R. Libby. 1997. Tacit managerial versus technical knowledge as determinants of audit expertise in the field. Journal of Accounting Research 35: 97-113.

Taylor, S.D. 2011. Does audit fee homogeneity exist? Premiums and discounts attributable to individual partners. Auditing: A Journal of Practice \& Theory 30: 249-272.

Vera-Munõz, S.C., J.L. Ho, and C.W. Chow. 2006. Enhancing knowledge sharing in public accounting firms. Accounting Horizons 20: 133-55.

Wilks, T.F. 2002. Predecisional distortion of evidence as a consequence of real-time audit review. The Accounting Review 77: 51-71. 
Ye, P., E. Carson, and R. Simnett. 2011. Threats to auditor independence: The impact of relationship and economic bonds. Auditing: A Journal of Practice \& Theory 30: 121-148.

Zerni, M. 2012. Audit partner specialization and audit fees: Some evidence from Sweden. Contemporary Accounting Research 29: 312-340.

Zmijewski, M.E. 1984. Methodological issues related to the estimation of financial distress prediction models. Journal of Accounting research 22: 59-82. 
Figure 1 IQ score distribution for audit partners

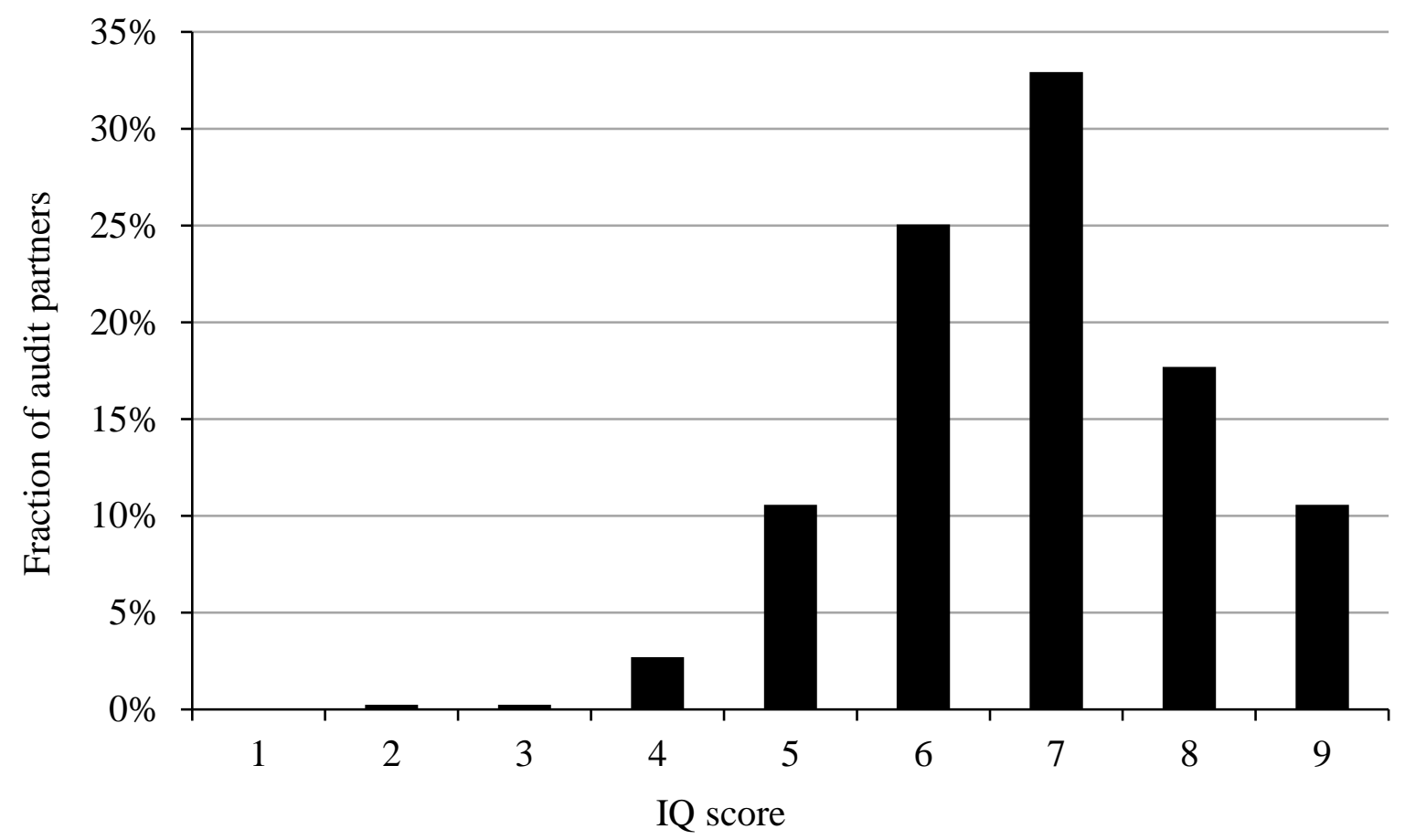

Notes:

The IQ scores range from one (the lowest IQ) to nine (the highest IQ) with a population average of five. The sample includes all 407 male audit partners who have acted as a lead or deputy auditor for at least one publicly listed Swedish company during the sample period from 2000 to 2009. 
TABLE 1

Audit partners' characteristics

Panel A: Descriptive statistics for personal characteristics variables

\begin{tabular}{lrrrrrc}
\hline & Mean & Median & SD & Min & Max & N \\
\hline IQ $_{i}$ & 6.82 & 7.00 & 1.26 & 2.00 & 9.00 & 407 \\
PROPLISTCL $_{i t}$ & 0.08 & 0.03 & 0.12 & 0.00 & 1.00 & 407 \\
INDSPEC $_{i t}$ & 0.36 & 0.30 & 0.30 & 0.00 & 1.00 & 407 \\
CAREER $_{i t}$ & 17.90 & 18.50 & 7.65 & 0.00 & 35.50 & 407 \\
NAUDITS $_{i t}$ & 67.75 & 52.00 & 54.23 & 4.50 & 307.40 & 407 \\
CRIME $_{i}$ & 0.16 & 0.00 & 0.37 & 0.00 & 1.00 & 407 \\
BIGN $_{i t}$ & 0.73 & 1.00 & 0.44 & 0.00 & 1.00 & 407 \\
\hline
\end{tabular}

Panel B: Means by audit partners' IQ

\begin{tabular}{lccccccc}
\hline & $\begin{array}{c}1-4 \\
\text { (Lowest) }\end{array}$ & 5 & 6 & 7 & 8 & $\begin{array}{c}9 \\
\text { (Highest) }\end{array}$ & $\begin{array}{c}\text { Diff: } \\
\text { Lowest - } \\
\text { Highest }\end{array}$ \\
\cline { 2 - 7 } & $\mathrm{N}=13$ & $\mathrm{~N}=43$ & $\mathrm{~N}=102$ & $\mathrm{~N}=134$ & $\mathrm{~N}=72$ & $\mathrm{~N}=43$ & \\
\hline PROPLISTCL $_{i t}$ & 0.03 & 0.08 & 0.07 & 0.07 & 0.09 & 0.10 & $-0.07 * * *$ \\
INDSPEC $_{i t}$ & 0.41 & 0.30 & 0.42 & 0.35 & 0.34 & 0.35 & 0.06 \\
CAREER $_{i t}$ & 18.81 & 17.03 & 16.70 & 18.55 & 19.21 & 17.11 & 1.69 \\
NAUDITS $_{i t}$ & 86.77 & 63.82 & 70.28 & 68.30 & 62.78 & 66.52 & 20.25 \\
CRIME $_{i}$ & 0.39 & 0.19 & 0.16 & 0.13 & 0.17 & 0.16 & $0.22^{*}$ \\
BIGN $_{i t}$ & 0.62 & 0.77 & 0.77 & 0.72 & 0.69 & 0.77 & -0.15 \\
\hline
\end{tabular}

Notes:

Table 1 presents descriptive statistics for variables that capture audit partner characteristics (panel A) and the mean values of the characteristics variables by an audit partner's IQ score (panel B). See the Appendix for variable definitions. In panel $\mathrm{B}$, we test whether the mean values of personal characteristics variables are significantly different between audit partners with the lowest IQ scores (IQ scores from one to four) and the highest IQ scores (IQ score of nine) by using a two-tailed $t$-test. As for the dummy variables INDSPEC $C_{i t}$, CRIMINAL $_{i t}$ and $B I G N_{i t}$, the numbers reported in the table show, for each level of audit partners' IQ, the proportions of industry specialist, criminally convicted, and Big N audit firm partners, respectively. The sample includes all 407 male audit partners who have acted as a lead or deputy auditor for at least one publicly listed Swedish company during the sample period from 2000 to 2009 . * and *** indicate significance at the 10 and 1 percent two-tailed levels, respectively. 
TABLE 2

Descriptive statistics for the variables used in the analyses

\begin{tabular}{|c|c|c|c|c|c|c|}
\hline Variable & Mean & Median & SD & Min & Max & $\begin{array}{c}\mathrm{N}(\text { Client- } \\
\text { years })\end{array}$ \\
\hline \multicolumn{7}{|c|}{ Panel A: Going-concern reporting accuracy analyses } \\
\hline$T O T A L \_E R R O R_{j t}$ & 0.010 & 0.000 & 0.101 & 0.000 & 1.000 & 122,012 \\
\hline$T Y P E \_\overline{1} \_E R R O R_{j t}$ & 0.005 & 0.000 & 0.074 & 0.000 & 1.000 & 121,273 \\
\hline$T Y P E \_2 \_E R R O R$ jt & 0.786 & 1.000 & 0.410 & 0.000 & 1.000 & 739 \\
\hline$I Q_{i}$ & 6.791 & 7.000 & 1.273 & 2.000 & 9.000 & 122,012 \\
\hline PROPLISTCL $L_{i t}$ & 0.036 & 0.011 & 0.073 & 0.000 & 1.000 & 122,012 \\
\hline$I_{N D S P E C}$ & 0.505 & 1.000 & 0.499 & 0.000 & 1.000 & 122,012 \\
\hline $\ln \left(1+C A R E E R_{i t}\right)$ & 2.929 & 3.045 & 0.423 & 0.000 & 3.689 & 122,012 \\
\hline $\ln \left(1+N A U D I T S_{i t}\right)$ & 4.789 & 4.868 & 0.627 & 1.099 & 6.234 & 122,012 \\
\hline$C R I M E_{i}$ & 0.179 & 0.000 & 0.382 & 0.000 & 1.000 & 122,012 \\
\hline $\ln \left(1+T E N U R E_{i j t}\right)$ & 1.623 & 1.609 & 0.523 & 0.693 & 2.398 & 122,012 \\
\hline INFLUENCE $E_{i j t}$ & 0.018 & 0.012 & 0.018 & 0.002 & 0.514 & 122,012 \\
\hline $\ln \left(S I Z E_{j t}\right)$ & 16.038 & 15.774 & 1.807 & 8.987 & 21.591 & 122,012 \\
\hline $\ln \left(C L I E N T A G E_{j t}\right)$ & 8.379 & 8.500 & 0.994 & 4.369 & 10.626 & 122,012 \\
\hline$L E V E R A G E_{j t}$ & 0.610 & 0.644 & 0.262 & 0.034 & 0.994 & 122,012 \\
\hline CURRENT $_{j t}$ & 2.536 & 1.502 & 3.962 & 0.041 & 29.931 & 122,012 \\
\hline $\ln \left(1+C O V E R A G E_{j t}\right)$ & 11.655 & 11.673 & 0.242 & 0.000 & 12.822 & 122,012 \\
\hline $\ln \left(P R O B Z_{j t}\right)$ & 0.104 & 0.066 & 0.128 & 0.000 & 1.000 & 122,012 \\
\hline$I N V E N T_{j t}$ & 0.126 & 0.004 & 0.201 & 0.000 & 0.849 & 122,012 \\
\hline$R O A_{j t}$ & 0.088 & 0.078 & 0.224 & -0.857 & 0.762 & 122,012 \\
\hline$L O S S_{j t}$ & 0.253 & 0.000 & 0.435 & 0.000 & 1.000 & 122,012 \\
\hline$E Q \_H A L F_{j t}$ & 0.005 & 0.000 & 0.071 & 0.000 & 1.000 & 122,012 \\
\hline$S U B S I D_{j t}$ & 0.392 & 0.000 & 0.488 & 0.000 & 1.000 & 122,012 \\
\hline$L_{L I S T E D_{j t}}$ & 0.009 & 0.000 & 0.093 & 0.000 & 1.000 & 122,012 \\
\hline \multicolumn{7}{|c|}{407 unique audit partners } \\
\hline 32,226 unique clients & & & & & & \\
\hline
\end{tabular}

Panel B: Audit fee analyses

\begin{tabular}{lcccccc}
\hline $\ln \left(\right.$ AUDITFEES $\left._{j t}\right)$ & 14.104 & 13.978 & 1.370 & 11.313 & 18.050 & 1,197 \\
IQ $_{i}$ & 6.835 & 7.000 & 0.944 & 4.000 & 9.000 & 1,197 \\
PROPLISTCL $_{i t}$ & 0.198 & 0.154 & 0.181 & 0.009 & 1.000 & 1,197 \\
INDSPEC $_{i t}$ & 0.507 & 0.500 & 0.388 & 0.000 & 1.000 & 1,197 \\
$\ln \left(1+\right.$ CAREER $\left._{i t}\right)$ & 3.002 & 3.045 & 0.302 & 1.099 & 3.611 & 1,197 \\
$\ln \left(1+N A U D I T S_{i t}\right)$ & 3.372 & 3.401 & 0.593 & 1.099 & 5.215 & 1,197 \\
CRIME $_{i}$ & 0.186 & 0.000 & 0.291 & 0.000 & 1.000 & 1,197 \\
$\ln \left(1+\right.$ TENURE $\left._{i j t}\right)$ & 1.570 & 1.609 & 0.393 & 0.693 & 2.398 & 1,197 \\
INFLUENCE $_{i j t}$ & 0.043 & 0.027 & 0.059 & 0.006 & 0.613 & 1,197 \\
$\ln \left(\right.$ SIZE $\left._{j t}\right)$ & 20.536 & 20.279 & 1.900 & 16.884 & 26.054 & 1,197 \\
$\ln \left(\right.$ CLIENTAGE $\left._{j t}\right)$ & 8.969 & 8.828 & 0.906 & 5.727 & 10.580 & 1,197 \\
LEVERAGE $_{j t}$ & 0.171 & 0.149 & 0.155 & 0.000 & 0.583 & 1,197 \\
CURRENT $_{j t}$ & 2.318 & 1.780 & 1.875 & 0.543 & 11.865 & 1,197 \\
$\ln \left(1+\right.$ COVERAGE $\left._{j t}\right)$ & 8.584 & 8.598 & 2.899 & 0.000 & 15.441 & 1,197 \\
$\ln \left(\right.$ PROBZ $\left._{j t}\right)$ & -3.771 & -3.957 & 1.500 & -8.250 & 14.115 & 1,197 \\
INVENT $_{j t}$ & 0.125 & 0.097 & 0.126 & 0.000 & 0.491 & 1,197 \\
\hline
\end{tabular}




\begin{tabular}{lcccccc}
\hline ROA $_{j t}$ & -0.030 & 0.041 & 0.233 & -0.973 & 0.318 & 1,197 \\
LOSS $_{j t}$ & 0.353 & 0.000 & 0.478 & 0.000 & 1.000 & 1,197 \\
JOINTAUDIT $_{j t}$ & 0.106 & 0.000 & 0.308 & 0.000 & 1.000 & 1,197 \\
FOREIGNSALES $_{j t}$ & 0.229 & 0.000 & 0.331 & 0.000 & 1.000 & 1,197 \\
EXCEPTION $_{j t}$ & 0.364 & 0.000 & 0.481 & 0.000 & 1.000 & 1,197 \\
PB $_{j t}$ & 2.776 & 1.951 & 2.751 & 0.352 & 21.724 & 1,197 \\
286 unique audit partners & & & & & \\
277 unique clients & & & & & & \\
\hline
\end{tabular}

Panel C: Abnormal accruals analyses

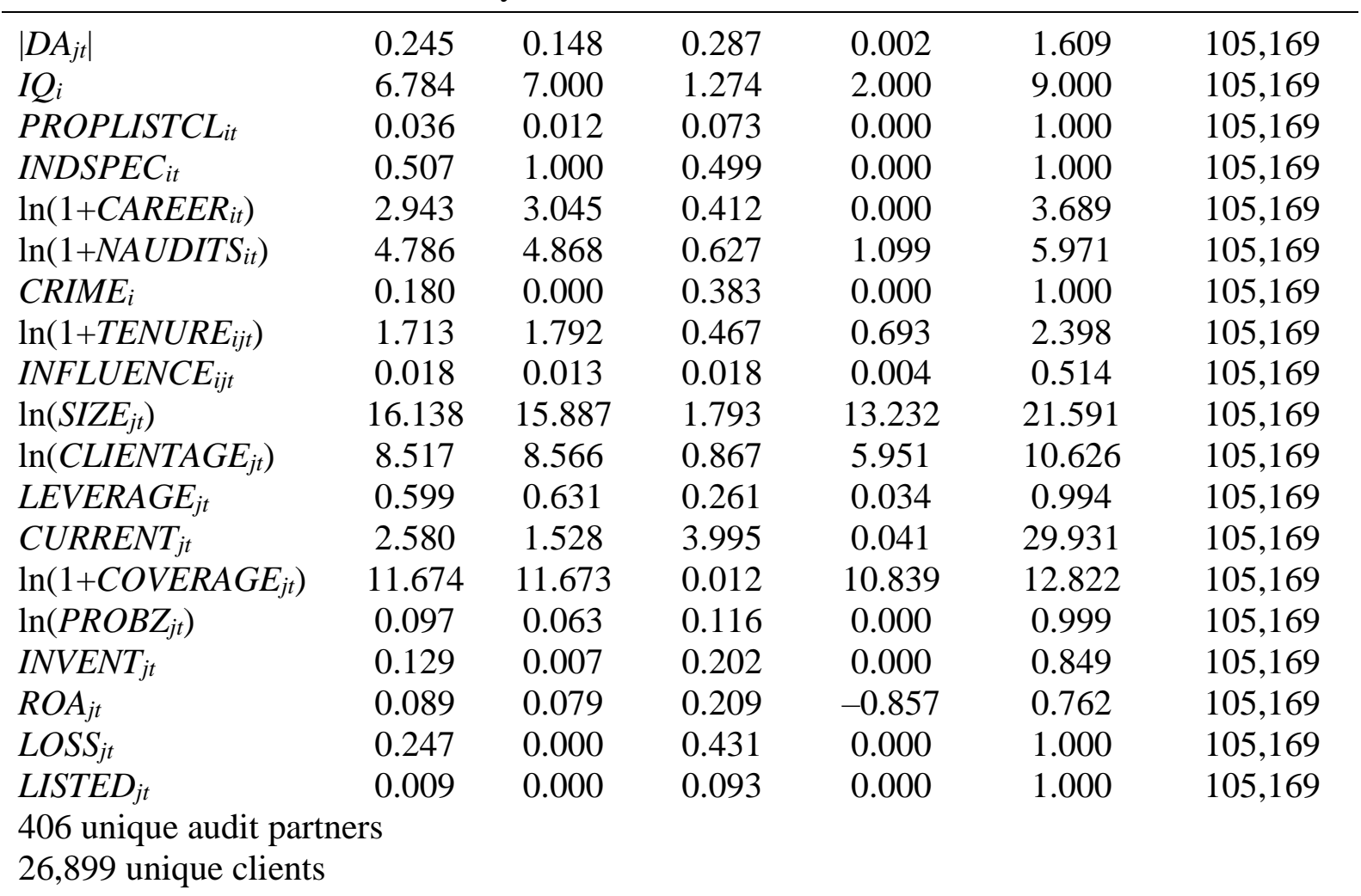

Notes:

Table 2 reports descriptive statistics for the variables used in the going-concern reporting accuracy (panel A), audit fee (panel B), and abnormal accruals (panel C) analyses. The sample in panels A and C (panel B) includes privately held and publicly listed clients (publicly listed clients) of all male audit partners who have acted as a lead or deputy auditor for at least one publicly listed Swedish company during the sample period from 2000 to 2009. See the Appendix for variable definitions. The variables $S_{\text {SIZE }}$ tt and AUDITFEES $S_{j t}$ are in SEK. All continuous variables are winsorized to the $1^{\text {st }}$ and $99^{\text {th }}$ percentiles of their distributions. 
TABLE 3

Univariate analysis of audit partner's IQ and going-concern reporting accuracy

\begin{tabular}{lccc}
\hline & \multicolumn{2}{c}{ Going-concern reporting error } & \\
\cline { 2 - 3 } & Yes & No & \multirow{2}{*}{$\begin{array}{c}\text { Difference: } \\
\text { Yes - No }\end{array}$} \\
\cline { 2 - 3 } Panel A: Full sample & Mean IQ & Mean IQ & \\
\hline Total reporting error & 6.69 & 6.79 & $-0.10^{* * *}$ \\
N (\# of unique audit partners) & $1,246(287)$ & $120,766(407)$ & $(2.63)$ \\
Type 1 reporting error & 6.64 & 6.79 & $-0.15^{* * *}$ \\
N (\# of unique audit partners) & $665(222)$ & $120,608(407)$ & $(2.99)$ \\
Type 2 reporting error & 6.75 & 6.95 & $-0.20^{*}$ \\
N (\# of unique audit partners) & $581(213)$ & $158(104)$ & $(1.84)$ \\
\hline Panel B: Reduced sample & & & \\
\hline Total reporting error & 6.67 & 6.79 & $-0.12^{* * *}$ \\
N (\# of unique audit partners) & $933(269)$ & $108,048(406)$ & $(2.65)$ \\
Type 1 reporting error & 6.58 & 6.79 & $-0.21^{* * * *}$ \\
N (\# of unique audit partners) & $385(177)$ & $107,929(406)$ & $(3.24)$ \\
Type 2 reporting error & 6.74 & 6.97 & $-0.23^{* * *}$ \\
N (\# of unique audit partners) & $548(208)$ & $119(87)$ & $(1.98)$ \\
\hline N & & & \\
\hline
\end{tabular}

Notes:

Table 3 reports the univariate results for the association between an audit partner's IQ and goingconcern reporting accuracy for both the full sample (panel A) and the reduced sample excluding clients in extreme financial distress, defined as those belonging to the $10^{\text {th }}$ decile of the variable PROBZ (panel B). Specifically, we test whether the mean IQ scores are significantly different between those audit partners who have issued an incorrect going-concern audit report and those who have not using a twotailed $t$-test. We conduct this analysis separately for Total reporting error (the sum of Type 1 and Type 2 reporting errors), and Type 1 and Type 2 reporting errors. The IQ score obtains values from one (the lowest IQ) to nine (the highest IQ). The sample includes 32,226 privately held and publicly listed clients of all 407 male audit partners who have acted as a lead or deputy auditor for at least one publicly listed Swedish company during the sample period from 2000 to 2009. See the Appendix for variable definitions. The $t$-statistics are presented in parentheses. *,**, and $* * *$ indicate significance at the 10 percent, 5 percent, and 1 percent two-tailed levels, respectively. 
TABLE 4

Regression analysis of audit partner's IQ and going-concern reporting accuracy

\begin{tabular}{|c|c|c|c|c|c|c|c|}
\hline & \multirow{2}{*}{$\begin{array}{l}\text { Pred. } \\
\text { sign }\end{array}$} & \multicolumn{2}{|c|}{$\begin{array}{l}\text { (1) } \text { Dependent variable }= \\
\text { TOTAL_ERROR } \text { f }_{j t}\end{array}$} & \multicolumn{2}{|c|}{$\begin{array}{l}\text { (2) Dependent variable }= \\
T Y P E_{-}{ }_{1} \_E R R O R_{j t}\end{array}$} & \multicolumn{2}{|c|}{$\begin{array}{l}\text { (3) Dependent variable }= \\
T Y P E \_2 \_E R R O R R_{j t}\end{array}$} \\
\hline & & Full sample & Reduced sample & Full sample & Reduced sample & Full sample & Reduced sample \\
\hline$I Q_{i}$ & - & $\begin{array}{l}-0.093 * * * \\
(-2.93)\end{array}$ & $\begin{array}{l}-0.130 * * * \\
(-3.32)\end{array}$ & $\begin{array}{l}-0.089 * * * \\
(-2.47)\end{array}$ & $\begin{array}{l}-0.142 * * * \\
(-3.18)\end{array}$ & $\begin{array}{l}-0.102 \\
(-1.12)\end{array}$ & $\begin{array}{l}-0.170 * * * \\
(-2.39)\end{array}$ \\
\hline PROPLISTCL $L_{i t}$ & - & $\begin{array}{l}0.495 \\
(0.85)\end{array}$ & $\begin{array}{l}0.824 \\
(1.12)\end{array}$ & $\begin{array}{r}0.427 \\
(0.60)\end{array}$ & $\begin{array}{l}1.187 * \\
(1.63)\end{array}$ & $\begin{array}{c}0.420 \\
(0.08)\end{array}$ & $\begin{array}{l}-1.462 \\
(-0.23)\end{array}$ \\
\hline$I_{N D S P E C}{ }_{i t}$ & - & $\begin{array}{l}-0.001 \\
(-0.01)\end{array}$ & $\begin{array}{l}0.119 \\
(1.05)\end{array}$ & $\begin{array}{l}0.016 \\
(0.16)\end{array}$ & $\begin{array}{l}0.189^{*} \\
(1.47)\end{array}$ & $\begin{array}{c}0.072 \\
(0.24)\end{array}$ & $\begin{array}{c}0.093 \\
(0.29)\end{array}$ \\
\hline $\ln \left(1+C A R E E R_{i t}\right)$ & $?$ & $\begin{array}{l}-0.022 \\
(-0.23)\end{array}$ & $\begin{array}{c}0.038 \\
(0.32)\end{array}$ & $\begin{array}{c}0.034 \\
(0.32)\end{array}$ & $\begin{array}{l}-0.002 \\
(-0.01)\end{array}$ & $\begin{array}{l}0.076 \\
(0.22)\end{array}$ & $\begin{array}{l}0.296 \\
(1.05)\end{array}$ \\
\hline $\ln \left(N A U D I T S_{i t}\right)$ & $?$ & $\begin{array}{l}-0.184 \\
(-1.41)\end{array}$ & $\begin{array}{l}-0.197 \\
(-1.39)\end{array}$ & $\begin{array}{l}-0.212 \\
(-1.39)\end{array}$ & $\begin{array}{l}-0.266 \\
(-1.42)\end{array}$ & $\begin{array}{l}-0.420 \\
(-0.76)\end{array}$ & $\begin{array}{l}-0.615 \\
(-1.59)\end{array}$ \\
\hline$C R I M E_{i}$ & $?$ & $\begin{array}{l}-0.118 \\
(-1.08)\end{array}$ & $\begin{array}{l}-0.085 \\
(-0.64)\end{array}$ & $\begin{array}{l}-0.106 \\
(-0.88)\end{array}$ & $\begin{array}{l}-0.092 \\
(-0.60)\end{array}$ & $\begin{array}{l}-0.264 \\
(-0.50)\end{array}$ & $\begin{array}{r}0.129 \\
(0.17)\end{array}$ \\
\hline $\ln \left(T E N U R E_{i j t}\right)$ & $?$ & $\begin{array}{c}0.065 \\
(0.68)\end{array}$ & $\begin{array}{c}0.026 \\
(0.23)\end{array}$ & $\begin{array}{c}0.059 \\
(0.54)\end{array}$ & $\begin{array}{c}0.045 \\
(0.33)\end{array}$ & $\begin{array}{l}-0.591 * * \\
(-2.10)\end{array}$ & $\begin{array}{l}-0.657 * * \\
(-1.98)\end{array}$ \\
\hline INFLUENCE $E_{i j t}$ & + & $\begin{array}{l}-2.474 \\
(-0.58)\end{array}$ & $\begin{array}{r}0.561 \\
(0.12)\end{array}$ & $\begin{array}{l}-2.834 \\
(-0.54)\end{array}$ & $\begin{array}{l}-0.883 \\
(-0.14)\end{array}$ & $\begin{array}{l}-44.256^{*} \\
(-1.33)\end{array}$ & $\begin{array}{l}-51.281 * * \\
(-2.05)\end{array}$ \\
\hline $\ln \left(S I Z E_{j t}\right)$ & - & $\begin{array}{l}0.078 * * * \\
(2.59)\end{array}$ & $\begin{array}{l}0.108 * * * \\
(2.87)\end{array}$ & $\begin{array}{l}0.077 * * \\
(2.25)\end{array}$ & $\begin{array}{l}0.123 * * * \\
(3.06)\end{array}$ & $\begin{array}{c}0.171 \\
(0.99)\end{array}$ & $\begin{array}{c}0.123 \\
(0.46)\end{array}$ \\
\hline $\ln \left(C L I E N T A G E_{j t}\right)$ & - & $\begin{array}{l}-0.036 \\
(-0.75)\end{array}$ & $\begin{array}{r}0.031 \\
(0.50)\end{array}$ & $\begin{array}{r}0.019 \\
(0.35)\end{array}$ & $\begin{array}{c}0.058 \\
(0.85)\end{array}$ & $\begin{array}{c}0.136 \\
(1.28)\end{array}$ & $\begin{array}{c}0.158 \\
(0.91)\end{array}$ \\
\hline$L E V E R A G E_{j t}$ & + & $\begin{array}{l}1.291 * * * \\
(5.53)\end{array}$ & $\begin{array}{l}1.089 * * * \\
(3.55)\end{array}$ & $\begin{array}{l}0.756^{* * * *} \\
(2.74)\end{array}$ & $\begin{array}{c}0.384 \\
(0.79)\end{array}$ & $\begin{array}{l}-1.232 \\
(-0.84)\end{array}$ & $\begin{array}{l}-1.042 \\
(-0.52)\end{array}$ \\
\hline CURRENT $_{j t}$ & - & $\begin{array}{l}-0.014 \\
(-0.99)\end{array}$ & $\begin{array}{l}-0.008 \\
(-0.47)\end{array}$ & $\begin{array}{l}-0.010 \\
(-0.50)\end{array}$ & $\begin{array}{l}-0.005 \\
(-0.27)\end{array}$ & $\begin{array}{c}0.046 \\
(0.40)\end{array}$ & $\begin{array}{c}0.019 \\
(0.15)\end{array}$ \\
\hline $\ln \left(1+C O V E R A G E_{j t}\right)$ & - & $\begin{array}{l}-1.902 * * * \\
(-37.32)\end{array}$ & $\begin{array}{l}-2.594 * * * \\
(-30.48)\end{array}$ & $\begin{array}{l}-0.206 \\
(-0.91)\end{array}$ & $\begin{array}{l}-0.196^{*} \\
(-1.55)\end{array}$ & $\begin{array}{l}2.283 * * * \\
(4.70)\end{array}$ & $\begin{array}{l}2.188 * * * \\
(2.66)\end{array}$ \\
\hline
\end{tabular}




\begin{tabular}{|c|c|c|c|c|c|c|c|}
\hline $\ln \left(P R O B Z_{j t}\right)$ & + & $\begin{array}{l}-2.607 * * * \\
(-5.65)\end{array}$ & $\begin{array}{l}-3.574 * * * \\
(-4.60)\end{array}$ & $\begin{array}{l}0.846^{* *} \\
(1.88)\end{array}$ & $\begin{array}{c}0.699 \\
(0.36)\end{array}$ & $\begin{array}{l}-0.108 \\
(-0.16)\end{array}$ & $\begin{array}{l}-0.924 \\
(-0.95)\end{array}$ \\
\hline$I N V E N T_{j t}$ & + & $\begin{array}{l}-0.668 * * * \\
(-2.62)\end{array}$ & $\begin{array}{l}-0.974 * * * \\
(-3.02)\end{array}$ & $\begin{array}{l}-0.989 * * * \\
(-3.32)\end{array}$ & $\begin{array}{l}-1.264 * * * \\
(-3.18)\end{array}$ & $\begin{array}{l}0.291^{*} \\
(1.50)\end{array}$ & $\begin{array}{c}0.284 \\
(0.69)\end{array}$ \\
\hline$R O A_{j t}$ & - & $\begin{array}{l}-0.921 * * * \\
(-3.30)\end{array}$ & $\begin{array}{l}-0.868 * * \\
(-2.17)\end{array}$ & $\begin{array}{l}-0.049 \\
(-0.15)\end{array}$ & $\begin{array}{l}-0.080 \\
(-0.18)\end{array}$ & $\begin{array}{r}0.259 \\
(0.97)\end{array}$ & $\begin{array}{l}-0.732 * * * \\
(-3.14)\end{array}$ \\
\hline $\operatorname{LOSS}_{j t}$ & + & $\begin{array}{l}0.730 * * * \\
(7.73)\end{array}$ & $\begin{array}{l}0.214 * \\
(1.48)\end{array}$ & $\begin{array}{l}0.531 * * * \\
(4.71)\end{array}$ & $\begin{array}{l}0.308 * * \\
(1.96)\end{array}$ & $\begin{array}{l}-0.610^{* * * *} \\
(-2.46)\end{array}$ & $\begin{array}{l}-0.595^{* *} \\
(-2.07)\end{array}$ \\
\hline$E Q \_H A L F_{j t}$ & + & $\begin{array}{l}1.753 * * * \\
(4.45)\end{array}$ & $\begin{array}{l}-0.943 * * \\
(-1.71)\end{array}$ & $\begin{array}{l}3.825 * * * \\
(23.36)\end{array}$ & $\begin{array}{l}4.068 * * * \\
(11.76)\end{array}$ & $\begin{array}{l}-3.488 * * * \\
(-6.14)\end{array}$ & $\begin{array}{l}-3.504 * * * \\
(-5.86)\end{array}$ \\
\hline$S U B S I D_{j t}$ & $?$ & $\begin{array}{l}-0.605^{* * *} \\
(-6.69)\end{array}$ & $\begin{array}{l}-0.804 * * * \\
(-6.81)\end{array}$ & $\begin{array}{l}-0.821^{* * *} \\
(-7.60)\end{array}$ & $\begin{array}{l}-1.018^{* * * *} \\
(-7.02)\end{array}$ & $\begin{array}{r}0.007 \\
(0.02)\end{array}$ & $\begin{array}{c}0.131 \\
(0.51)\end{array}$ \\
\hline LISTED $_{j t}$ & $?$ & $\begin{array}{l}-0.725^{*} \\
(-1.73)\end{array}$ & $\begin{array}{l}-1.881 * * * \\
(-4.52)\end{array}$ & $\begin{array}{l}-1.660 * * \\
(-2.30)\end{array}$ & $\begin{array}{l}-11.774 * * * \\
(-41.72)\end{array}$ & $\begin{array}{l}9.301 * * * \\
(9.02)\end{array}$ & $\begin{array}{l}8.020 * * * \\
(4.79)\end{array}$ \\
\hline Intercept & & Yes & Yes & Yes & Yes & Yes & Yes \\
\hline Year fixed effects & & Yes & Yes & Yes & Yes & Yes & Yes \\
\hline Credit rating fixed effects & & Yes & Yes & Yes & Yes & Yes & Yes \\
\hline Audit firm fixed effects & & Yes & Yes & Yes & Yes & Yes & Yes \\
\hline Industry fixed effects & & Yes & Yes & Yes & Yes & Yes & Yes \\
\hline Clustered standard errors & & Client & Client & Client & Client & Audit firm & Audit firm \\
\hline Pseudo R-squared & & $43.86 \%$ & $54.24 \%$ & $22.61 \%$ & $17.98 \%$ & $60.02 \%$ & $57.80 \%$ \\
\hline LR-ratio $\left(\chi^{2}\right)$ & & $5,904.12 * * *$ & $5,694.73 * * *$ & $1,816.94 * * *$ & $901.16^{* * *}$ & $362.43 * * *$ & $289.13 * * *$ \\
\hline $\mathrm{N}$ (\# of errors) & & $122,012(1,246)$ & $108,981(933)$ & $121,273(665)$ & $108,314(385)$ & $739(581)$ & $667(548)$ \\
\hline
\end{tabular}

\section{Notes:}

Table 4 reports the logistic regression results for the association between an audit partner's IQ and going-concern reporting accuracy for both the full sample and the reduced sample excluding clients in extreme financial distress (defined as those belonging to the $10^{\text {th }}$ decile of the variable $P R O B Z_{j, t}$ ). Column 1 reports the results for Total reporting error. Columns (2) and (3) report the results for Type 1 and Type 2 reporting errors, respectively. See the Appendix for variable definitions. The sample includes 32,226 privately held and publicly listed clients of all 407 male audit partners who have acted as a lead or deputy auditor for at least one publicly listed Swedish company during the sample period from 2000 to 2009 . All continuous variables are winsorized to the $1^{\text {st }}$ and $99^{\text {th }}$ percentiles of their distributions. The $z$-statistics from robust standard errors clustered at the client (columns 1 and 2) or audit firm (column 3) level are presented in parentheses. $*, * *$, and $* * *$ indicate significance at the 10 percent, 5 percent, and 1 percent one-tailed (two-tailed) levels for variables with (without) a predicted sign, respectively. 
TABLE 5

Univariate analysis of audit partner's IQ and audit fees

$\begin{array}{ll}\text { (1) Full sample } & \text { (2) Reduced sample }\end{array}$

\begin{tabular}{lcclccc}
\cline { 2 - 7 } Audit fee quartile & $\mathrm{N}$ & $\begin{array}{c}\text { Mean audit } \\
\text { fees }\end{array}$ & Mean IQ & $\mathrm{N}$ & $\begin{array}{c}\text { Mean audit } \\
\text { fees }\end{array}$ & Mean IQ \\
\hline Quartile 1(lowest) & 299 & 0.293 & 6.58 & 223 & 0.356 & 6.60 \\
Quartile 2 & 299 & 0.805 & 6.63 & 220 & 0.959 & 6.67 \\
Quartile 3 & 300 & 1.862 & 6.97 & 229 & 2.254 & 6.98 \\
Quartile 4 (highest) & 299 & 13.259 & 7.16 & 222 & 16.419 & 7.15 \\
Difference: Q1 - Q4 & & -12.966 & $-0.58^{* * *}$ & & -16.063 & $-0.55^{* * *}$ \\
\hline
\end{tabular}

Notes:

Table 5 reports the univariate results for the association between an audit partner's IQ and audit fees for both the full sample (column 1) and the reduced sample excluding clients that have not changed their audit partner during the sample period (column 2). Audit fees are sorted into quartiles, where Quartile 1 (Quartile 4) includes the lowest (highest) fees. We test whether the mean IQ scores are significantly different between Quartiles 1 and 4 by using a (two-tailed) $t$-test. The IQ score obtains values from one (the lowest IQ) to nine (the highest IQ). The sample includes 277 publicly listed clients of all 286 male audit partners who have acted as a lead or deputy auditor for at least one publicly listed Swedish company during the sample period from 2000 to 2009. Audit fees are in million SEK. The $t$-statistics are presented in parentheses. $* * *$ indicates significance at the 1 percent two-tailed level. 
TABLE 6

Regression analysis of audit partner's IQ and audit fees

\begin{tabular}{|c|c|c|c|}
\hline & \multirow[b]{2}{*}{ Pred. sign } & \multicolumn{2}{|c|}{ Dependent variable $=\ln \left(A U D I T F E E S_{j t}\right)$} \\
\hline & & (1) Full sample & (2) Reduced sample \\
\hline$I Q_{i}$ & + & $\begin{array}{l}0.064 * * * \\
(2.40)\end{array}$ & $\begin{array}{l}0.051^{*} \\
(1.63)\end{array}$ \\
\hline PROPLISTCL $L_{i t}$ & + & $\begin{array}{c}0.112 \\
(1.04)\end{array}$ & $\begin{array}{l}-0.076 \\
(-0.76)\end{array}$ \\
\hline$I N D S P E C_{i t}$ & + & $\begin{array}{l}-0.109 * * \\
(-2.12)\end{array}$ & $\begin{array}{r}0.035 \\
(0.97)\end{array}$ \\
\hline $\ln \left(1+C A R E E R_{i t}\right)$ & $?$ & $\begin{array}{c}0.053 \\
(0.66)\end{array}$ & $\begin{array}{l}-0.100^{*} \\
(-1.56)\end{array}$ \\
\hline $\ln \left(1+N A U D I T S_{i t}\right)$ & $?$ & $\begin{array}{l}-0.163 * * * \\
(-2.95)\end{array}$ & $\begin{array}{l}-0.038 \\
(-0.84)\end{array}$ \\
\hline$C R I M E_{i}$ & + & $\begin{array}{l}0.167 * * \\
(2.16)\end{array}$ & $\begin{array}{l}0.175^{* *} \\
(1.85)\end{array}$ \\
\hline $\ln \left(1+T E N U R E_{i j t}\right)$ & $?$ & $\begin{array}{l}-0.020 \\
(-0.32)\end{array}$ & $\begin{array}{l}0.055^{*} \\
(1.34)\end{array}$ \\
\hline INFLUENCE $E_{i j t}$ & - & $\begin{array}{l}-0.539 \\
(-1.23)\end{array}$ & $\begin{array}{l}-0.654 * * \\
(-2.25)\end{array}$ \\
\hline $\ln \left(S I Z E_{j t}\right)$ & + & $\begin{array}{l}0.599 * * * \\
(25.87)\end{array}$ & $\begin{array}{l}0.356^{* * *} \\
(8.65)\end{array}$ \\
\hline $\ln \left(C L I E N T A G E_{j t}\right)$ & + & $\begin{array}{r}0.027 \\
(0.75)\end{array}$ & $\begin{array}{c}0.101 \\
(0.60)\end{array}$ \\
\hline$L E V E R A G E_{j t}$ & + & $\begin{array}{l}-0.122 \\
(-0.64)\end{array}$ & $\begin{array}{l}0.641 \text { *** } \\
(3.08)\end{array}$ \\
\hline$C U R R E N T_{j t}$ & - & $\begin{array}{l}-0.083 * * * \\
(-5.27)\end{array}$ & $\begin{array}{l}-0.066 * * * \\
(-3.31)\end{array}$ \\
\hline $\ln \left(1+C O V E R A G E_{j t}\right)$ & - & $\begin{array}{l}-0.039 * * * \\
(-2.95)\end{array}$ & $\begin{array}{l}-0.019 * * \\
(-1.94)\end{array}$ \\
\hline $\ln \left(P R O B Z_{j t}\right)$ & + & $\begin{array}{c}0.032 \\
(0.72)\end{array}$ & $\begin{array}{l}-0.090 * * * \\
(-3.64)\end{array}$ \\
\hline$I N V E N T_{j t}$ & + & $\begin{array}{l}-0.011 \\
(-0.04)\end{array}$ & $\begin{array}{l}0.431 * \\
(1.35)\end{array}$ \\
\hline$R O A_{j t}$ & - & $\begin{array}{l}-0.089 \\
(-0.33)\end{array}$ & $\begin{array}{l}-0.657 * * * \\
(-3.49)\end{array}$ \\
\hline $\operatorname{LOSS}_{j t}$ & + & $\begin{array}{l}-0.002 \\
(-0.03)\end{array}$ & $\begin{array}{c}0.018 \\
(0.43)\end{array}$ \\
\hline JOINTAUDIT $_{j t}$ & + & $\begin{array}{c}0.100 \\
(1.28)\end{array}$ & $\begin{array}{l}0.232 * * * \\
(2.40)\end{array}$ \\
\hline FOREIGNSALES $S_{j t}$ & + & $\begin{array}{l}0.127^{*} \\
(1.52)\end{array}$ & $\begin{array}{r}0.067 \\
(0.89)\end{array}$ \\
\hline$E_{\text {EXCEPTION }}$ & + & $\begin{array}{l}0.079 * * * \\
(2.52)\end{array}$ & $\begin{array}{l}0.073 * * * \\
(3.33)\end{array}$ \\
\hline$P B_{j t}$ & + & $\begin{array}{c}0.010 \\
(1.21)\end{array}$ & $\begin{array}{l}-0.012 * \\
(-1.61)\end{array}$ \\
\hline Intercept & & Yes & Yes \\
\hline Year fixed effects & & Yes & Yes \\
\hline
\end{tabular}




\begin{tabular}{lcc}
\hline Credit rating fixed effects & Yes & Yes \\
Audit firm fixed effects & Yes & Yes \\
Industry fixed effects & Yes & No \\
Client fixed effects & No & Yes \\
Clustered standard errors & Client & Client \\
Adj. R-squared & $88.52 \%$ & $96.47 \%$ \\
$\mathrm{~N}$ & 1,197 & 894 \\
\hline
\end{tabular}

Notes:

Table 6 reports the OLS regression results for the association between an audit partner's IQ and audit fees for both the full sample (column 1) and the reduced sample excluding clients that have not changed their audit partner during the sample period (column 2). See the Appendix for variable definitions. The sample includes 277 publicly listed clients of all 286 male audit partners who have acted as a lead or deputy auditor for at least one publicly listed Swedish company during the sample period from 2000 to 2009. All continuous variables are winsorized to the $1^{\text {st }}$ and $99^{\text {th }}$ percentiles of their distributions. The $t$-statistics from robust standard errors clustered at the client level are presented in parentheses. *, **, and *** indicate significance at the 10 percent, 5 percent, and 1 percent one-tailed (two-tailed) levels for variables with (without) a predicted sign, respectively. 
TABLE 7

Univariate analysis of audit partner's IQ and abnormal accruals

\begin{tabular}{lccccccc}
\hline \multirow{2}{*}{$\begin{array}{l}\text { Abnormal accruals } \\
\text { quintile }\end{array}$} & \multicolumn{2}{c}{ (1) All } & \multicolumn{2}{c}{ (2) Income-increasing } & \multicolumn{2}{c}{ (3) Income-decreasing } \\
\cline { 2 - 7 } & Mean $|D A|$ & \multicolumn{2}{c}{ Mean IQ } & \multicolumn{2}{c}{ Mean IQ } & \multicolumn{2}{c}{ Mean IQ } \\
\cline { 2 - 7 } & & Full sample & Reduced sample & Full sample & Reduced sample & Full sample & Reduced sample \\
\hline \multirow{2}{*}{ Quintile 1 (lowest) } & 0.023 & 6.80 & 6.77 & 6.82 & 6.80 & 6.78 & 6.73 \\
& $\mathrm{~N}=21,033$ & $\mathrm{~N}=21,033$ & $\mathrm{~N}=2,285$ & $\mathrm{~N}=10,757$ & $\mathrm{~N}=1,182$ & $\mathrm{~N}=10,276$ & $\mathrm{~N}=1,103$ \\
Quintile 2 & 0.075 & 6.77 & 6.77 & 6.79 & 6.79 & 6.75 & 6.75 \\
& $\mathrm{~N}=21,034$ & $\mathrm{~N}=21,034$ & $\mathrm{~N}=2,286$ & $\mathrm{~N}=10,758$ & $\mathrm{~N}=1,182$ & $\mathrm{~N}=10,276$ & $\mathrm{~N}=1,104$ \\
Quintile 3 & 0.149 & 6.78 & 6.72 & 6.78 & 6.71 & 6.79 & 6.74 \\
& $\mathrm{~N}=21,034$ & $\mathrm{~N}=21,034$ & $\mathrm{~N}=2,285$ & $\mathrm{~N}=10,758$ & $\mathrm{~N}=1,182$ & $\mathrm{~N}=10,277$ & $\mathrm{~N}=1,103$ \\
Quintile 4 & 0.276 & 6.78 & 6.80 & 6.79 & 6.78 & 6.77 & 6.81 \\
& $\mathrm{~N}=21,034$ & $\mathrm{~N}=21,034$ & $\mathrm{~N}=2,286$ & $\mathrm{~N}=10,758$ & $\mathrm{~N}=1,182$ & $\mathrm{~N}=10,276$ & $\mathrm{~N}=1,104$ \\
Quintile 5 (highest) & 0.705 & 6.79 & 6.74 & 6.78 & 6.73 & 6.79 & 6.76 \\
& $\mathrm{~N}=21,034$ & $\mathrm{~N}=21,034$ & $\mathrm{~N}=2,285$ & $\mathrm{~N}=10,757$ & $\mathrm{~N}=1,182$ & $\mathrm{~N}=10,276$ & $\mathrm{~N}=1,103$ \\
Difference: Q1 - Q5 & -0.682 & 0.01 & 0.03 & $0.04 *$ & 0.07 & -0.01 & -0.03 \\
& & $(0.69)$ & $(0.67)$ & $(1.88)$ & $(1.25)$ & $(-0.81)$ & $(-0.49)$ \\
\hline
\end{tabular}

Notes:

Table 7 reports the univariate results for the association between an audit partner's IQ and abnormal accruals for both the full sample and the reduced sample excluding clients that have not changed their auditor during the sample period. Column (1) reports the results for the absolute value of abnormal accruals when both positive (income-increasing) and negative (income-decreasing) abnormal accruals are included. Columns (2) and (3) report the results for the absolute value of income-increasing and income-decreasing abnormal accruals, respectively. In each column, abnormal accruals are sorted into quintiles, where Quintile 1 (Quintile 5) includes the lowest (highest) abnormal accruals. We test whether the mean IQ scores are significantly different between Quintiles 1 and 5 by using a two-tailed $t$-test. The IQ score obtains values from one (the lowest IQ score) to nine (the highest IQ score). The sample includes 26,899 privately held and publicly listed clients of all 406 male audit partners who have acted as a lead or deputy auditor for at least one publicly listed Swedish company during the sample period from 2000 to 2009. See the Appendix for variable definitions. The $t$-statistics are presented in parentheses. * indicates significance at the 10 percent two-tailed level. 
TABLE 8

Regression analysis of audit partner's IQ and abnormal accruals

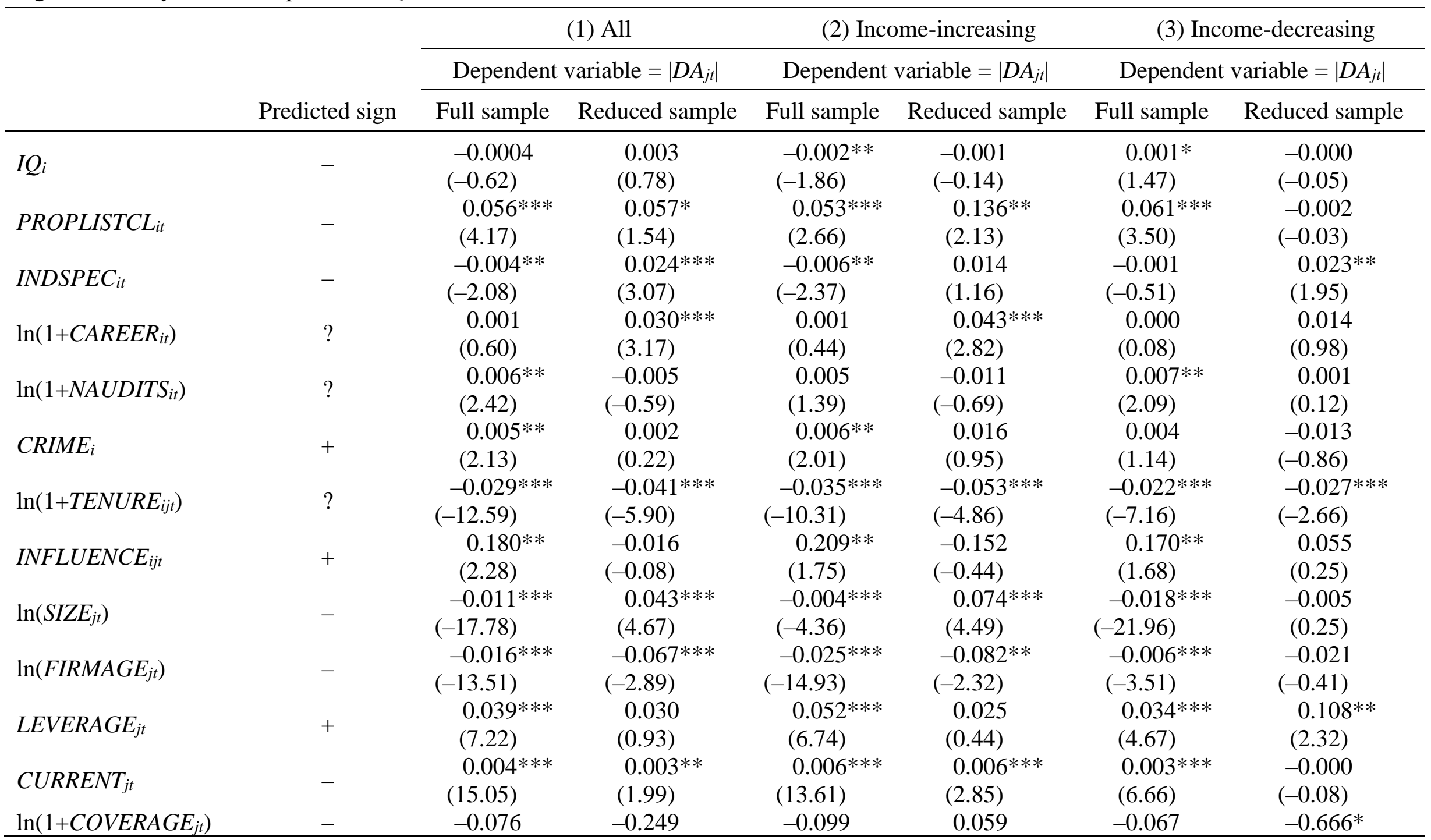




\begin{tabular}{|c|c|c|c|c|c|c|c|}
\hline \multirow{3}{*}{$\ln \left(P R O B Z_{j t}\right)$} & \multirow{3}{*}{+} & $(-1.11)$ & $(-0.83)$ & $(-0.91)$ & $(0.12)$ & $(-0.84)$ & $(-1.41)$ \\
\hline & & $0.196^{* * *}$ & 0.012 & $0.135 * * *$ & $-0.175^{* *}$ & $0.224 * * *$ & 0.070 \\
\hline & & $(13.17)$ & $(0.23)$ & $(5.67)$ & $(-1.75)$ & $(11.97)$ & $(0.90)$ \\
\hline \multirow{2}{*}{$I N V E N T_{j t}$} & \multirow{2}{*}{+} & $0.048 * * *$ & -0.027 & $0.168 * * *$ & $0.216^{* *}$ & $-0.104^{* * *}$ & $-0.307 * * *$ \\
\hline & & $(7.35)$ & $(-0.38)$ & $(17.64)$ & $(1.94)$ & $(-12.93)$ & $(-3.45)$ \\
\hline \multirow{2}{*}{$R O A_{j t}$} & \multirow{2}{*}{$?$} & $0.131 * * *$ & $0.056^{*}$ & $0.174 * * *$ & $0.135^{* *}$ & $0.090 * * *$ & -0.000 \\
\hline & & $(16.89)$ & $(1.71)$ & $(14.81)$ & $(2.46)$ & $(8.94)$ & $(-0.01)$ \\
\hline \multirow{2}{*}{$\operatorname{LOSS}_{j t}$} & \multirow{2}{*}{$?$} & $0.015^{* * *}$ & 0.012 & $0.013 * * *$ & 0.018 & $0.020 * * *$ & 0.009 \\
\hline & & $(5.72)$ & $(1.27)$ & $(3.46)$ & $(1.17)$ & $(5.68)$ & $(0.65)$ \\
\hline \multirow{2}{*}{ LISTED $_{j t}$} & \multirow{2}{*}{-} & $-0.039 * * *$ & $-0.494 *$ & $-0.048 * * *$ & -0.167 & $-0.022 * *$ & -0.226 \\
\hline & & $(-4.60)$ & $(-5.57)$ & $(-3.88)$ & $(-1.14)$ & $(-1.93)$ & $(-1.89)$ \\
\hline & Yes & Yes & Yes & Yes & Yes & Yes \\
\hline \multicolumn{2}{|l|}{ Year fixed effects } & Yes & Yes & Yes & Yes & Yes & Yes \\
\hline \multicolumn{2}{|l|}{ Credit rating fixed effects } & Yes & Yes & Yes & Yes & Yes & Yes \\
\hline \multicolumn{2}{|l|}{ Audit firm fixed effects } & Yes & Yes & Yes & Yes & Yes & Yes \\
\hline \multicolumn{2}{|l|}{ Industry fixed effects } & Yes & No & Yes & No & Yes & No \\
\hline \multicolumn{2}{|l|}{ Client fixed effects } & No & Yes & No & Yes & No & Yes \\
\hline \multicolumn{2}{|l|}{ Clustered standard errors } & Client & Client & Client & Client & Client & Client \\
\hline \multicolumn{2}{|l|}{ Adj. R-squared } & $7.08 \%$ & $16.78 \%$ & $9.46 \%$ & $19.25 \%$ & $8.12 \%$ & $16.80 \%$ \\
\hline \multicolumn{2}{|l|}{$\mathrm{N}$} & 105,169 & 11,427 & 53,788 & 5,910 & 51,381 & 5,517 \\
\hline
\end{tabular}

\section{Notes:}

Table 8 reports the OLS regression results for the association between an audit partner's IQ and abnormal accruals for both the full sample and the reduced sample excluding clients that have not changed their auditor during the sample period. Column (1) reports the results for the absolute value of abnormal accruals when both positive (income-increasing) and negative (income-decreasing) abnormal accruals are included. Columns (2) and (3) report the results for the absolute value of income-increasing and income-decreasing abnormal accruals, respectively. See the Appendix for variable definitions. The sample includes 26,899 privately held and publicly listed clients of all 406 male audit partners who have acted as a lead or deputy auditor for at least one publicly listed Swedish company during the sample period from 2000 to 2009 . The $t$-statistics from robust standard errors clustered at the client level are presented in parentheses. $*$, **, and $* * *$ indicate significance at the 10 percent, 5 percent, and 1 percent one-tailed (two-tailed) levels for variables with (without) a predicted sign. 